\title{
Florida Crop/Pest Profile: Sugarcane ${ }^{1}$
}

\section{P. Rott, D. C. Odero, J. M. Beuzelin, R. N. Raid, M. VanWeelden, S. Swanson, and M. Mossler ${ }^{2}$}

Sugarcane (Saccharum interspecific hybrids) is the main source of sugar in the world. It is grown in more than 90 countries in tropical and subtropical regions. Cultivation techniques and production challenges vary by location (Rott 2017; Rott 2018). This document discusses characteristics of the sugarcane crop and pests affecting its production in Florida, which is the largest producer of sugarcane in the United States.

\section{Sugarcane Production Facts}

- In 2016, Florida ranked first nationally in value of sugar produced from sugarcane, which was approximately $\$ 561$ million. That amount was $48 \%$ of the total US value of sugar from sugarcane that year. In general, the amount of sugar produced from sugarcane in Florida is more than $21 \%$ of the total amount of sugar produced from sugar beet and sugarcane in the United States (USDA 2017).

- Florida, Louisiana, and Texas are the only areas in the United States where sugarcane is grown commercially (Figure 1). Over 401,000 acres of sugarcane were harvested in 2016 in Florida, producing over 16 million tons of sugarcane and over 2 million tons of sugar (USDA 2017).

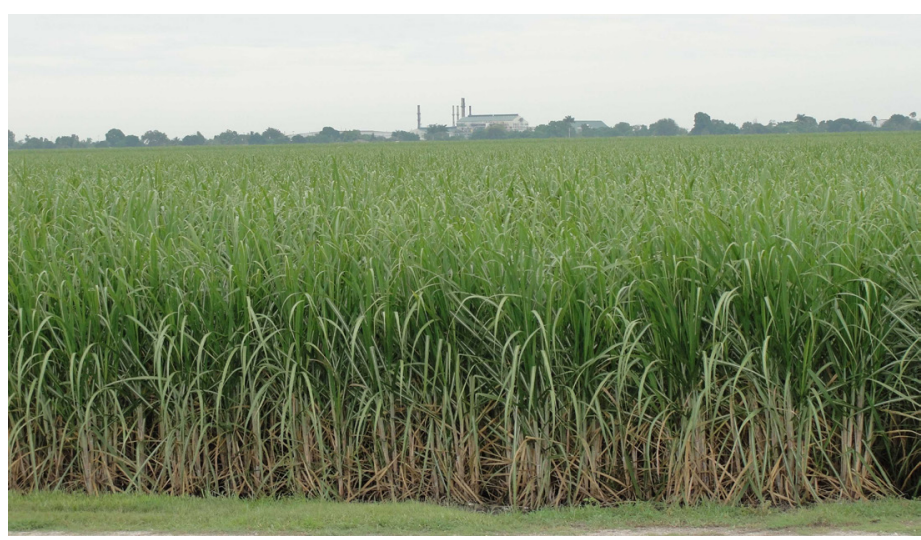

Figure 1. Sugarcane field in Belle Glade, Florida. Credits: Philippe Rott, UF/IFAS

- Sugarcane is Florida's most valuable field crop, worth more economically than all other field crops grown in Florida, including corn, cotton, peanuts, soybean, and tobacco, combined. In terms of Florida's overall agricultural crop economy, sugarcane ranks fourth, behind the greenhouse/nursery industry, vegetables, and citrus (USDA 2017).

- All Florida sugarcane is crushed at one of four mills in south Florida (Figure 2). Sugarcane milling companies grow about two-thirds of the cane; the remainder is produced by independent farmers. Sugar mills produce

1. This document is PI-171, one of a series of the Agronomy Department, UF/IFAS Extension. Original publication date August 2008. Revised May 2018. Visit the EDIS website at http://edis.ifas.ufl.edu.

2. P. Rott, professor, Plant Pathology Department; D. C. Odero, associate professor, Agronomy Department; J. M. Beuzelin, assistant professor, Entomology Department; R. N. Raid, professor, Plant Pathology Department, UF/IFAS Everglades Research and Education Center; M. VanWeelden, agronomic crops Extension agent, UF/IFAS Extension Palm Beach County; S. Swanson, regional sugarcane Extension agent III, UF/IFAS Extension Hendry County; and M. Mossler, former pest management specialist, Pesticide Information Office; UF/IFAS Extension, Gainesville, FL 32611.

The use of trade names in this publication is solely for the purpose of providing specific information. UF/IFAS does not guarantee or warranty the products named, and references to them in this publication do not signify our approval to the exclusion of other products of suitable composition. All chemicals should be used in accordance with directions on the manufacturer's label. Use pesticides safely. Read and follow directions on the manufacturer's label. 
raw sugar, which is a combination of sucrose and molasses and is light in color (Figure 3). The raw sugar is then refined at two refineries in the region or shipped by barge to other refineries on the East Coast. The refined sugar is the familiar white crystal and is $100 \%$ sucrose. Some sugar is marketed in its raw state (Baucum and Rice 2009).

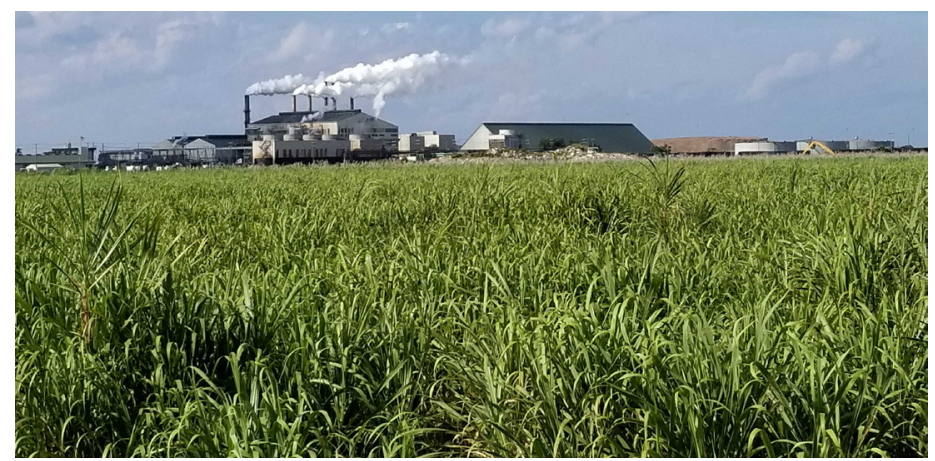

Figure 2. Sugarcane mill in Belle Glade, Florida.

Credits: Philippe Rott, UF/IFAS

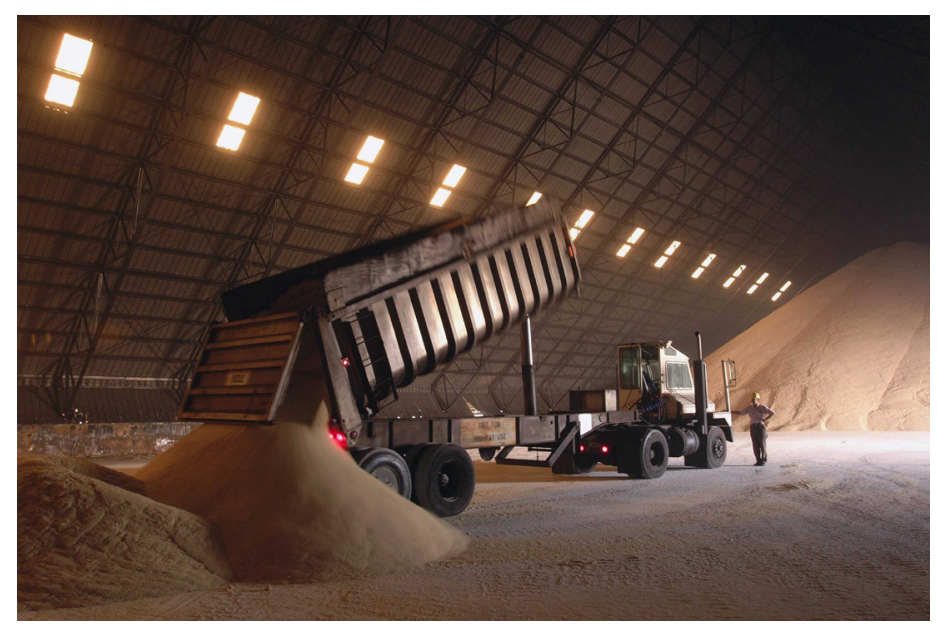

Figure 3. Raw sugar being stored before refining. Credits: Eric Zamora, UF/IFAS

\section{Regions of Sugarcane Production in Florida}

Sugarcane, a tropical grass, is adapted to all regions of Florida. However, the commercial sugarcane industry is located in south Florida around Lake Okeechobee, especially in the Everglades Agricultural Area. The vast majority of sugarcane production in Florida (70\% of the acreage and $75 \%$ of the tonnage) is produced in Palm Beach County. The remainder of commercial sugarcane production in Florida occurs in the adjacent counties of Hendry, Glades, Highlands, and Martin (Baucum and Rice 2009). While most sugarcane is grown on organic soils (also known as muck soils) which predominate near Lake Okeechobee, approximately $26 \%$ of Florida's commercial sugarcane production is on mineral (sand) soils (VanWeelden et al. 2017).

\section{Sugarcane Production Practices}

Sugarcane is a multi-year crop that can be grown perennially in Florida. Sugarcane is propagated vegetatively. Following harvest of the first "plant cane" crop, the regrowth ("ratoon cane") is harvested about once each year until plant population and yield decline. Typically, an average of three annual crops (one plant cane and two ratoon crops) will be harvested from a sugarcane field before the field is plowed under and replanted.

Most sugarcane is planted from September through December. Portions of a mature sugarcane field are reserved to grow "seed cane": whole, mature stalks cut directly from the field by machine or laborers with machetes.

Stalks of seed cane are dropped into furrows, two stalks beside each other, and then cut by hand into smaller pieces. These are covered with soil 3-8 inches deep (Figures 4 and 5). Less than $5 \%$ is planted mechanically. One acre of seed cane results in approximately 10 acres of plant cane when hand-planted. However, when mechanically planted, one acre of seed cane yields approximately four acres. In other words, it takes up to three times more seed to plant sugarcane mechanically than manually.

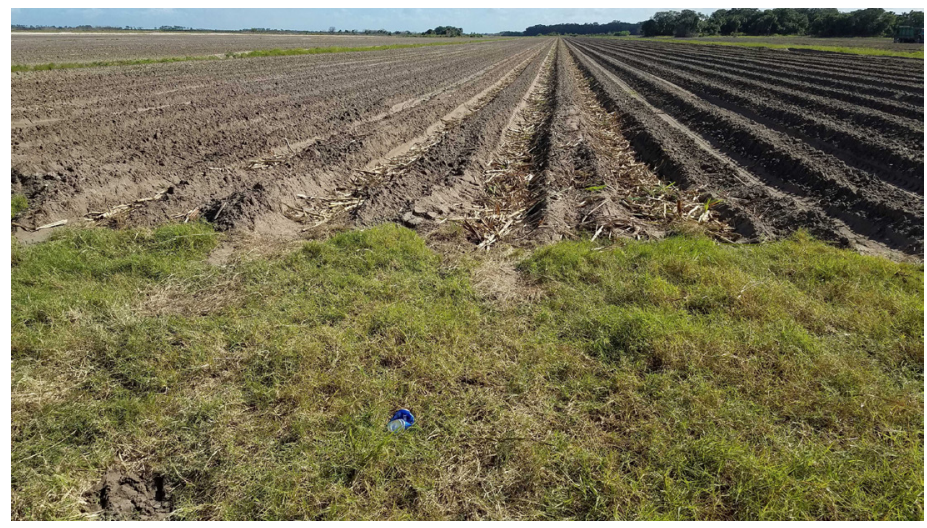

Figure 4. Sugarcane being planted in furrows. Credits: Stewart Swanson, UF/IFAS

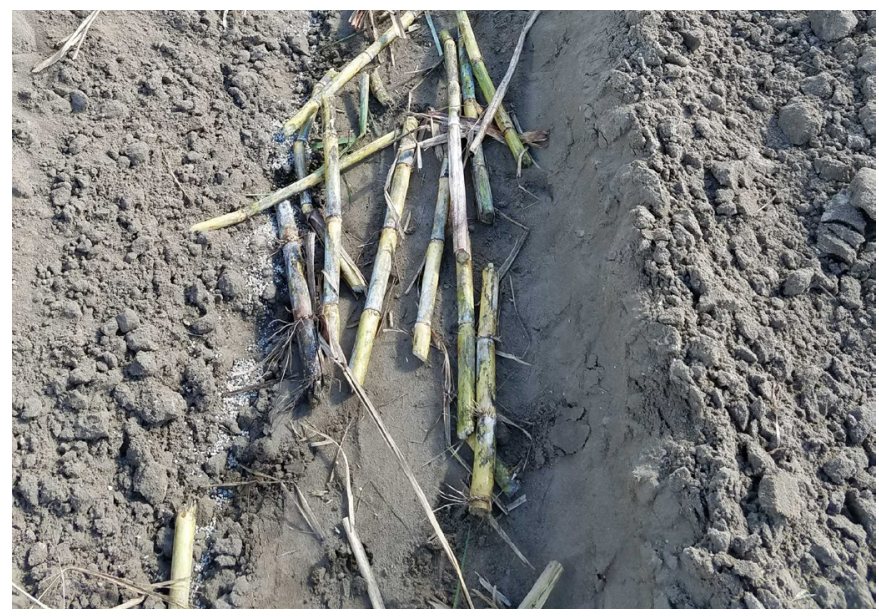

Figure 5. Sugarcane stalks in a furrow before being covered with soil. Credits: Stewart Swanson, UF/IFAS 
If a sugarcane field in its final harvest is taken out early enough in the growing season (before January), the field will likely be replanted to sugarcane in a process known as successive planting. If the field is harvested at a later date, replanting may be delayed until the following season because approximately 12 months are needed for sugarcane to become fully mature. During this fallow period, the field is often planted to another crop, such as rice, sweet corn, or a cover crop (termed regular or fallow planting).

In $2016-2017,32 \%$ of the sugarcane crop in Florida was plant cane, and $68 \%$ was ratoon cane. During that same growing season, $43 \%$ of the sugarcane was planted successively while the remainder was planted following a fallow period or rotational crop (VanWeelden et al. 2017).

Sugarcane is typically harvested from October through May. Sugar yields generally increase as the weather turns cooler. In order to complete the entire south Florida sugarcane harvest within the optimal time frame, some fields must be harvested before sugarcane plants have reached maximum yield potential. Research has examined which cultivars should be harvested in early-, mid-, or late-season (Sandhu et al. 2016b). One of several ripening agents is usually sprayed on sugarcane that is harvested early in the season in order to promote maturity and increase sugar content of the stalks (Sandhu et al. 2016a).

The fields are burned to remove field trash (excess leafy foliage), and then mechanically harvested. Cane is loaded onto trucks or rail cars to be transported to the mill.

\section{Worker Activities}

The only part of sugarcane cultivation that requires field workers is planting, $95 \%$ of which is conducted manually. Approximately 120,000 acres are planted each year. A single worker may plant up to five acres per day.

\section{Insect/Mite Management in Florida Sugarcane Crops}

Insects and mites that feed on sugarcane in Florida can increase production costs and decrease yield, even though sugarcane cultivars are relatively resistant to pests that are common in semi-tropical environments. Pests of concern in Florida include wireworms, white grubs, the sugarcane borer, the lesser cornstalk borer, aphids, and the sugarcane rust mite. The sugarcane delphacid, West Indian canefly, sugarcane lace bug, West Indian cane weevil, Diaprepes root weevil, American bird grasshopper, and spider mites also feed on sugarcane and can be sporadic pests (Cherry,
Nuessly, and Sandhu 2015; Nuessly, Cherry, and Sandhu 2015). The Mexican rice borer is an invasive insect occurring in central Florida where sugarcane is not commercially produced. This insect is expected to be a pest when it becomes established in the south Florida sugarcane production region (Hayden 2012).

\section{Insect and Mite Pests in Florida Sugarcane Crops WIREWORMS}

Wireworms are the larvae of click beetles (Figure 6). At least 12 species of wireworms have been found in south Florida, but only the corn wireworm, Melanotus communis, is considered to cause significant economic damage to sugarcane. Wireworms feed on the buds and root primordia during germination of sugarcane seed pieces. After germination, wireworms feed on shoots and roots. Most of the injury to young shoots occurs where the shoots join the seed piece or ratoon stubble (Cherry 2017; Cherry, Nuessly, and Sandhu 2015).

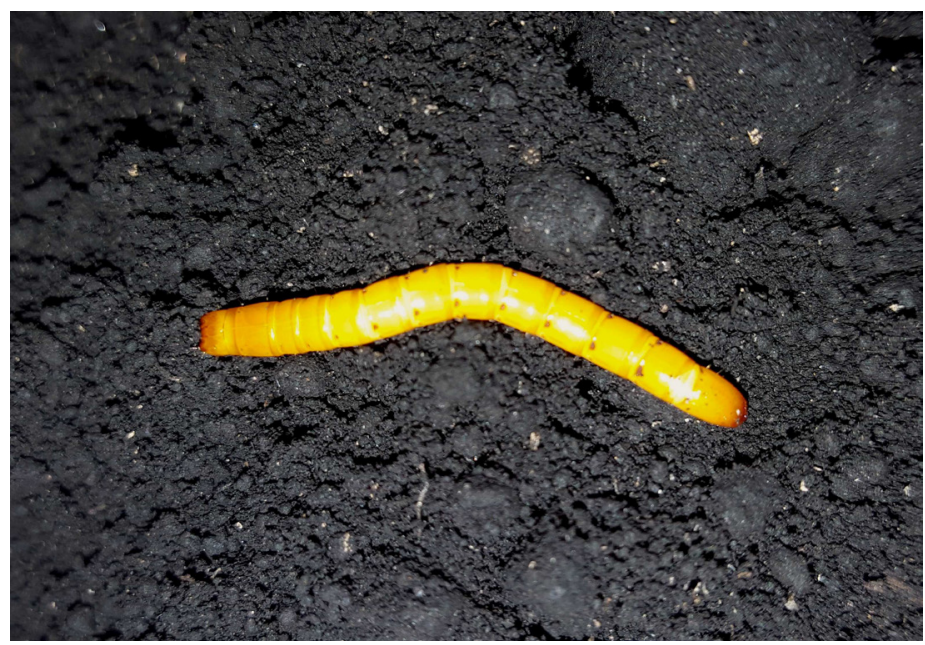

Figure 6. Larva of the corn wireworm, Melanotus communis. Credits: Mike Karounos, UF/IFAS

Generally, wireworms are a pest of newly planted sugarcane. They are only rarely a pest in ratoon sugarcane. Relatively large, ragged holes in buds or young shoots are signs of wireworm injury. The death of buds and young shoots leads to stand reduction. Wireworm injury to sugarcane also facilitates infections by the fungus that causes sugarcane red rot disease. $M$. communis has been a more significant pest for sugarcane grown on organic soil than sugarcane grown on mineral soil (Cherry 2017; Cherry, Nuessly, and Sandhu 2015). Wireworm densities appear to have decreased recently in organic soils, potentially because of the implementation of best management practices as well as soil subsidence, which results in higher water tables and more frequent flooding (Cherry, McCray, and Sandhu 2017). 


\section{WHITE GRUBS}

White grubs are the larvae of several beetle species in the genera Tomarus, Cyclocephala, Phyllophaga, and Anomala (Figure 7). Among these pests, Tomarus subtropicus is considered the most damaging species. White grubs tend to infest sugarcane in organic soils, damaging sugarcane by feeding on roots and underground stems. The first symptom of an infestation is yellowing of the leaves (chlorosis), usually followed by stunted growth, dense browning, lodging, plant uprooting, and in heavily infested areas, plant death. White grub infestations are generally low in plant cane fields, but they increase in ratoon cane fields (Cherry 2012; Cherry, Nuessly, and Sandhu 2015).

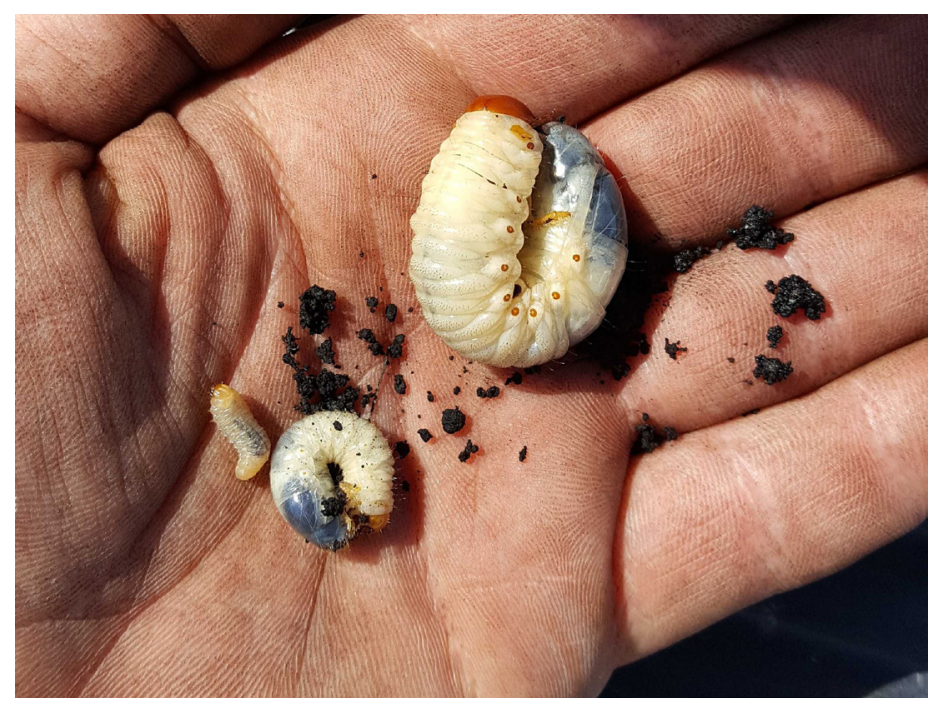

Figure 7. Beetle larvae infesting sugarcane, including a Diaprepes root weevil larva (left), a Cyclocephala sp. larva (center), and a Tomarus subtropicus larva (right).

Credits: Mike Karounos, UF/IFAS

Sugarcane fields infested with T. subtropicus may need to be replanted because ratoon growth and yield can be severely reduced by this pest. Heavily infested areas may not be worth harvesting. Thus, white grubs have historically been considered highly damaging insects to Florida sugarcane (Cherry 2012; Cherry, Nuessly, and Sandhu 2015). However, their population levels also seem to have decreased, potentially due to higher water tables and more frequent flooding in shallow organic soils (Cherry, McCray, and Sandhu 2017).

\section{SUGARCANE BORER}

The sugarcane borer (SCB), Diatraea saccharalis, is the larva of a moth (Figure 8). Although sugarcane is this insect's principal host, many other grasses, including rice, have been reported as alternative hosts. SCB tunneling into sugarcane stalks causes loss of stalk weight (tonnage/ acre) and sucrose yield. Weakened stalks are also subject to breaking and lodging. Additionally, SCB tunnels are points of entry for secondary invaders. SCB larvae feeding on young sugarcane plants and boring near the shoot meristem can also kill the shoot, resulting in a "deadheart" (Cherry, Nuessly, and Sandhu 2015). One study of five commercial cultivars showed that one bored internode per stalk reduced sugar yield by 5.6 pounds per ton of sugarcane. The range of sugar loss was 2.3 to 6.7 pounds per ton of sugarcane. Another study showed that bored internodes produce $45 \%$ less sugar than uninjured internodes (Hall, Nuessly, and Gilbert 2007).

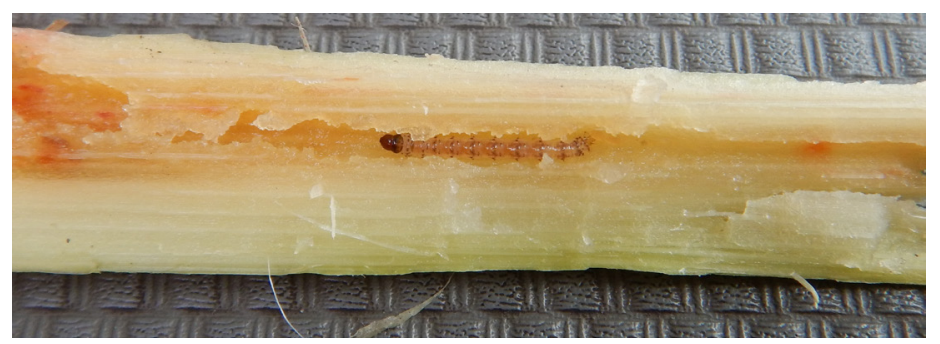

Figure 8. A sugarcane borer larva feeding inside a sugarcane stalk. Credits: Julien Beuzelin, UF/IFAS

The SCB has historically been considered the most important aboveground pest of sugarcane in Florida. The pest has been the focus of scouting programs that assessed pest and parasitoid population levels every two or three weeks from March through November. Detecting two to three live and non-parasitized larvae per 100 sampled stalks was generally enough to trigger an insecticide application (Hall, Nuessly, and Gilbert 2007; Cherry, Nuessly, and Sandhu 2015). However, SCB population levels have declined since the 1990s; this change is likely associated with successful biological control from natural enemies. Scouting programs and insecticide applications have been discontinued. Although the insect could re-emerge as a severe pest problem, the SCB is currently not considered a threat to sugarcane production in Florida.

\section{LESSER CORNSTALK BORER}

The lesser cornstalk borer (LCB), Elasmopalpus lignosellus, is the larva of a moth. LCB larvae (Figure 9) bore into young sugarcane plants at or below the soil surface and usually cause a deadheart comparable to injury caused by the SCB or wireworms. However, LCB larvae construct a silken tube in the soil that extends outward from the plant. The presence of silken tubes and small, circular entrance holes distinguishes deadhearts caused by LCB from those caused by SCB and wireworms. LCB injury above the plant growing point appears as rows of holes in emerging leaves (Cherry, Nuessly, and Sandhu 2015).

Most of the damage from the LCB occurs during dry periods and for crops grown on mineral soils. Emerging 
sugarcane shoots in plant cane fields are especially susceptible to LCB feeding. Deadhearts can lead to stand loss and delay shoot growth, while leaf injury can decrease photosynthesis. Ratoon cane usually recovers better from LCB feeding than young plant cane does. Yield loss varies with sugarcane cultivar. For example, CP 89-2143 is more susceptible than CP 78-1628 (Sandhu, Baucum, and Nuessly 2012).

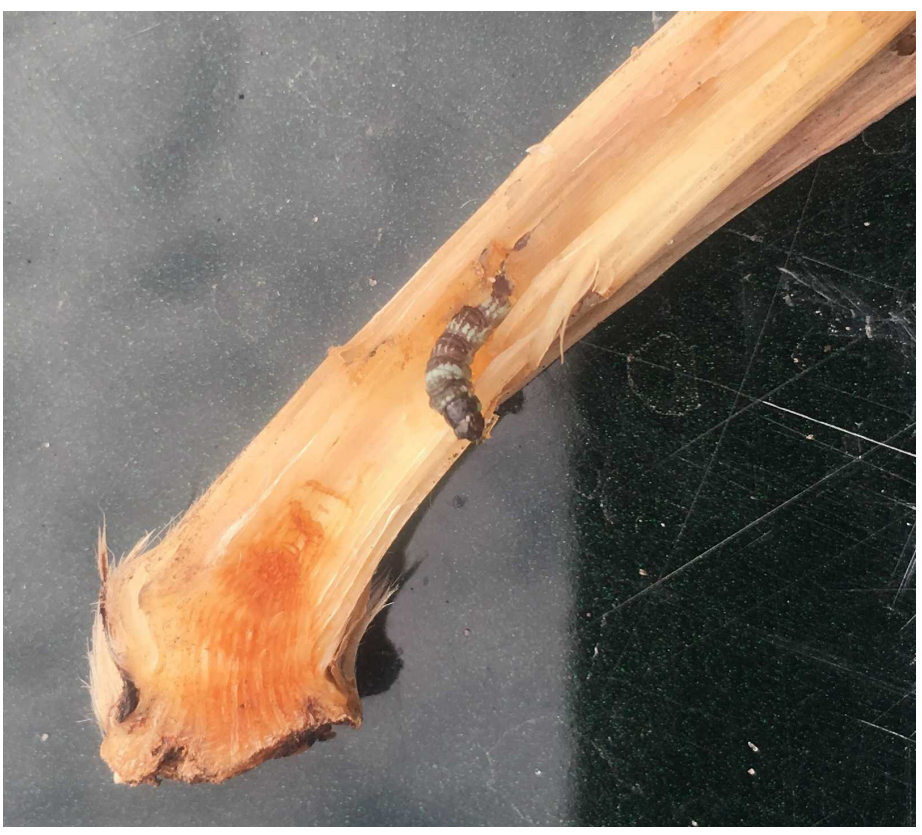

Figure 9. A lesser cornstalk borer larva feeding on a young sugarcane shoot.

Credits: Julien Beuzelin, UF/IFAS

\section{APHIDS}

Two aphid species, the yellow sugarcane aphid (YSA), Sipha flava, and the sugarcane aphid (SA), Melanaphis sacchari, infest sugarcane in Florida. The YSA is bright yellow with short, stiff hairs covering its body (Figure 10), whereas the SA is whitish and hairless (Figure 11) (Nuessly, Cherry, and Sandhu 2015). YSA feeding causes yellowing, reddening, or purpling of affected leaves, which may eventually die under severe infestations. This injury can result in reduced tillering in young sugarcane plants or in reduced growth. SA feeding does not cause visible injury to sugarcane leaves; however, large amounts of honeydew excreted by the SA are associated with the development of sooty mold. Sooty mold is a black fungus that can interfere with photosynthesis. In addition, the SA can transmit the sugarcane yellow leaf virus, which is responsible for yellow leaf disease of sugarcane (see below). Aphids observed feeding on sugarcane are generally wingless, but winged forms are produced under conditions unfavorable to the aphids. Abundant rainfall generally reduces aphid infestations (Nuessly, Cherry, and Sandhu 2015).

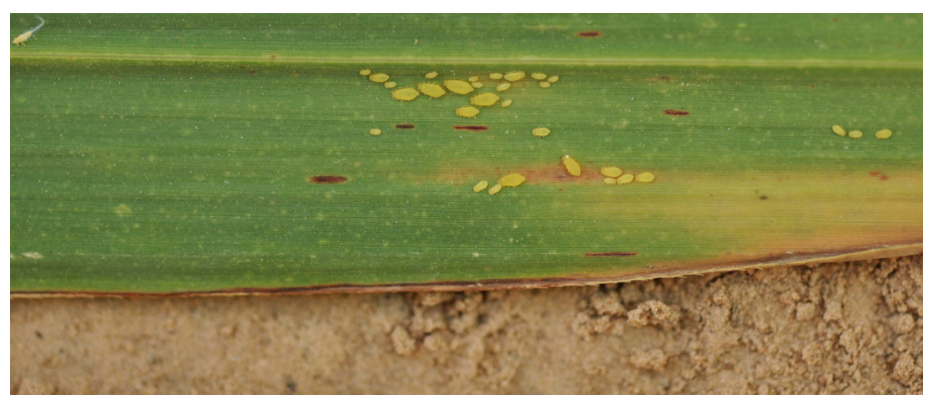

Figure 10. A yellow sugarcane aphid colony feeding on the underside of a sugarcane leaf.

Credits: Julien Beuzelin, LSU AgCenter

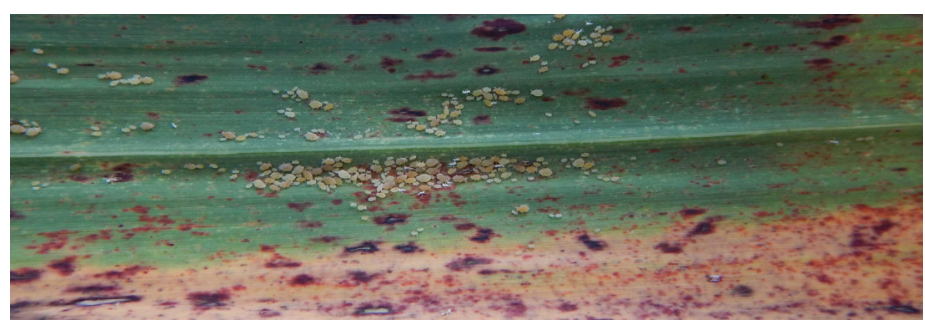

Figure 11. Sugarcane aphids feeding on a sugarcane leaf. Credits: Julien Beuzelin, UF/IFAS

\section{SUGARCANE RUST MITE}

The sugarcane rust mite (SRM), Abacarus sacchari, was originally identified as Abacarus officinari while observed feeding on sugarcane in the Everglades Agricultural Area in 1982. It was not until 2007 that the mite was observed again and correctly identified as A. sacchari. In 2014, Florida sugarcane sustained widespread SRM infestations (Nuessly, Cherry, and Sandhu 2015). SRM infestations can be present year-round, increasing throughout the summer. The mites are extremely small and invisible to the naked eye. However, the injury they cause consists of orange to reddish-brown flecks on the underside of leaves (Figure 12). The upper side of leaves and midribs can also exhibit injury under heavy infestations. Injury symptoms and severity depend on sugarcane cultivar and can be confused with orange rust symptoms; however, SRM injury does not cause pustules and tends to be more uniformly distributed on leaves. Injury interferes with photosynthesis and transpiration (Nuessly, Cherry, and Sandhu 2015).

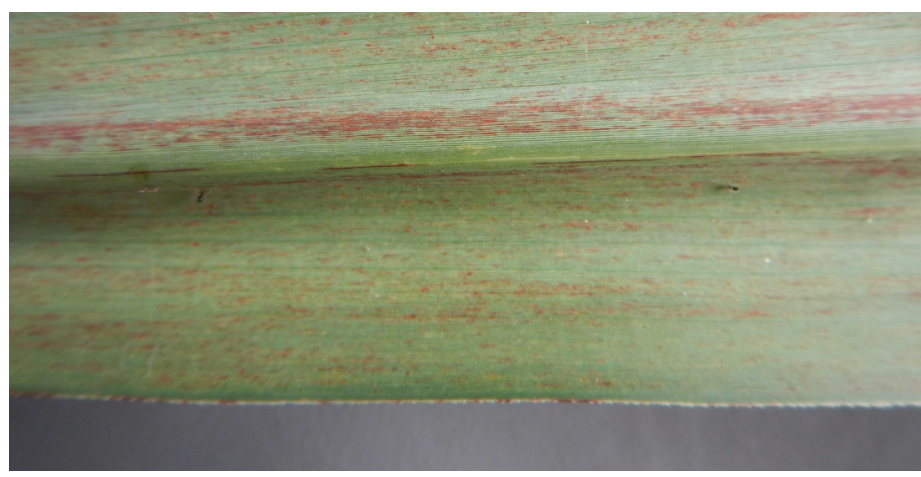

Figure 12. Sugarcane rust mite injury. Sugarcane rust mites are too small to be visible to the naked eye.

Credits: Julien Beuzelin, UF/IFAS 


\section{Cultural Management of Insects and Mites in Florida Sugarcane Crops}

Growing sugarcane cultivars with reduced susceptibility to insects and mites can play a key role in a successful pest management program. Cultivars with high susceptibility to insect and mite pests are eliminated during the selection process conducted by the breeding program that develops new cultivars for commercial release. When information on susceptibility to common pests is available, it can help sugarcane growers select cultivars adapted to their needs (Cherry, Nuessly, and Sandhu 2015; Nuessly, Cherry, and Sandhu 2015; Sandhu and Davidson 2017). Additional cultural practices can be implemented to manage insects and mites in Florida sugarcane.

For wireworms, flooding during late spring and summer will kill the wireworms and prevent egg-laying by the adult click beetles. Thus, flooding fallow fields or growing flooded rice as a rotation crop reduces wireworm infestations. Flooding can be effective with a minimum of six weeks of continuous flooding during the summer. Longer flooding periods are needed during colder months (Cherry 2017).

For white grubs, short-term flooding of the standing crop is an effective but impractical management tactic. Short-term flooding is most efficient in August, when water temperatures are warm, rainfall is abundant, and grubs initiate feeding. Discing infested fields and decreasing the number of ratoon crops also reduce white grub infestations (Cherry 2012).

For LCB, leaving green cane harvest residue (trash) on the soil surface decreases injury; however, most sugarcane fields in Florida are burned before harvest, and the presence of a trash blanket interferes with water percolation as well as fertilizer and herbicide applications (Sandhu, Baucum, and Nuessly 2012). Raising water levels in infested fields to prevent egg laying is another practice that can reduce LCB pest pressure (Cherry, Nuessly, and Sandhu 2015).

\section{Biological Management of Insects and Mites in Florida Sugarcane Crops}

Natural enemies, such as predators, parasitoids, and pathogenic fungi and bacteria, are not thought to significantly contribute to control of wireworms and white grubs in Florida sugarcane (Cherry 2012; Cherry 2017). However, relatively low SCB population levels observed in recent years have been attributed to successful biological control. Alabagrus stigma and Cotesia flavipes are two introduced wasp parasitoids of SCB larvae. A. stigma is a large, solitary (one-per-host) parasitoid that is active year-round, whereas C. flavipes is a small, gregarious (many-per-host) parasitoid that is most active after July. After initial introductions of C. flavipes in the 1960s, a commercial program of frequent field releases was implemented between the early 1990s and 2000s. C. flavipes alone is currently considered to effectively control SCB populations (Hall, Nuessly, and Gilbert 2007; Cherry, Nuessly, and Sandhu 2015). However, the red imported fire ant, Solenopsis invicta, which became established in the Florida sugarcane production region in the 1970s, is also thought to decrease SCB populations.

Natural enemies of the YSA include ten species of lady beetles and several species of flower flies. These beetles and flies can greatly reduce YSA populations. However, reduction in the size of a YSA infestation by natural enemies may not occur before the aphids cause plant injury. Outbreaks of the SA are uncommon in Florida because natural enemies of the YSA also prey on the SA. Additionally, red imported fire ants and predatory earwigs exert some control over the two aphid species (Nuessly, Cherry, and Sandhu 2015).

\section{Chemical Management of Insects and Mites in Florida Sugarcane Crops}

Two organophosphate insecticides, phorate (Thimet 20G) and ethoprop (Mocap 15G), are registered for application on sugarcane seed pieces in the open furrow at planting to control wireworms (Cherry, Nuessly, and Sandhu 2015). Phorate is applied to the majority of newly planted sugarcane fields. These at-planting applications are preventive by nature.

Insecticides registered for foliar applications include several pyrethroids (e.g., beta-cyfluthrin, esfenvalerate, gammacyhalothrin, lambda-cyhalothrin, zeta-cypermethrin). These broad-spectrum insecticides are generally not used. However, lambda-cyhalothrin was shown to decrease infestations of sugarcane thrips during an outbreak in 2017. A premix of a pyrethroid and a diamide, lambda-cyhalothrin and chlorantraniliprole (Besiege), is also registered and is commonly used to control LCB infestations.

Although SCB populations no longer require insecticide applications, two insect growth regulators, tebufenozide (Confirm) and novaluron (Diamond), as well as the diamide chlorantraniliprole (Coragen, Prevathon), are registered and effective. The premix Besiege is registered and can also effectively control SCB infestations. 


\section{Disease Management in Florida Sugarcane Crops}

Although more than 60 diseases affecting sugarcane have been reported throughout the world, only a few have impacted Florida sugarcane production (Rott et al. 2000). Leaf scald caused by Xanthomonas albilineans (Rott et al. 2017), ratoon stunting caused by Leifsonia xyli subsp. xyli (Rott et al. 2014a), smut caused by Sporisorium scitamineum (Rott and Comstock 2015), pokkah boeng caused by several Fusarium species (Raid and Rott 2015), and mosaic caused by Sugarcane mosaic virus (Rott et al. 2015) are a few of the diseases that have been targeted by the sugarcane breeding program at the USDA Sugarcane Field Station in Canal Point, FL. The development and release of resistant commercial cultivars have successfully limited the impact of the aforementioned diseases.

However, successful disease management through plant resistance has been more difficult for diseases such as brown rust caused by Puccinia melanocephala (Raid and Comstock 2006), orange rust caused by Puccinia kuehnii (Rott et al. 2014b), and yellow leaf caused by Sugarcane yellow leaf virus (Comstock, Sandhu, and Odero 2015). Until 2008, no fungicides were used in the Florida sugarcane industry to control diseases. However, fungicides had to be used to maintain acceptable yields following the first outbreak of orange rust in Florida in 2007 because several major cultivars grown at the time were susceptible to this disease. In 2000, the absence of reliable screening methods for resistance to yellow leaf called for the production of disease-free nurseries using young plantlets obtained by sugarcane meristem culture in the laboratory. For these reasons, brown rust, orange rust, and yellow leaf are currently considered Florida's most significant sugarcane diseases (Rott et al. 2016).

\section{Disease Pests in Florida Sugarcane Crops BROWN RUST}

Brown rust of sugarcane, formerly known as common rust, is currently found almost everywhere sugarcane is grown. It was first reported in the Western Hemisphere in 1978 in the Dominican Republic and was observed soon after in most sugarcane growing locations in the Americas, including Florida in 1979 (Purdy, Liu, and Dean 1983). The spread of brown rust has had considerable economic impact in Florida. During the 1987-1988 crop season, yield losses of at least $20 \%$ and economic losses over $\$ 40$ million were attributed to brown rust on cultivar CP72-1210, which occupied more than $60 \%$ of the sugarcane acreage (Raid and Comstock 2006). In 1988, yield loss estimates averaged 39\% in cultivar CP78-1247 (Comstock, Shine, and Raid 1992). As a result, developing cultivars resistant to brown rust became a major objective of the $\mathrm{CP}$ breeding program (Rott et al. 2016). However, in Florida, brown rust has a history of overcoming disease resistance in cultivars that previously demonstrated resistance (Comstock, Glynn, and Davidson 2010). Important cultivars, such as CP72-1210, CP74-2005, and CP78-1628, that did not show symptoms of brown rust for several years following release had to be withdrawn from commercial production because of the breakdown in resistance. These frequent breakdowns of rust resistance were attributed to the appearance of new and more virulent strains of the pathogen (Raid 1989).

Brown rust is a foliar disease. The pathogen does not infect the sugarcane stalk (Figure 13). The earliest symptoms are small and elongated yellowish spots that are visible on both the upper and the lower leaf surfaces. The spots increase in size, turn brown to orange-brown or red-brown in color, and develop a slight but definite chlorotic halo. Over time, leaf spots on susceptible cultivars develop into pustules above the leaf surface, with fungal sporulation breaking through the leaf epidermis. Lesions resulting from brown rust are seldom more than $1-3 \mathrm{~mm}$ in width. The lesions typically range from $2-10 \mathrm{~mm}$ in length, but they occasionally reach $30 \mathrm{~mm}$ in length (Egan 1964; Ryan and Egan 1989). Symptoms of brown rust infection are usually most numerous toward the leaf tip and become less numerous toward the base. Pustules (also called uredinia) that produce spores are most prevalent on the lower leaf surface, although pustules may appear on the upper leaf surface of certain sugarcane cultivars. Pustules may remain active for a while during cool seasons with long dew periods.

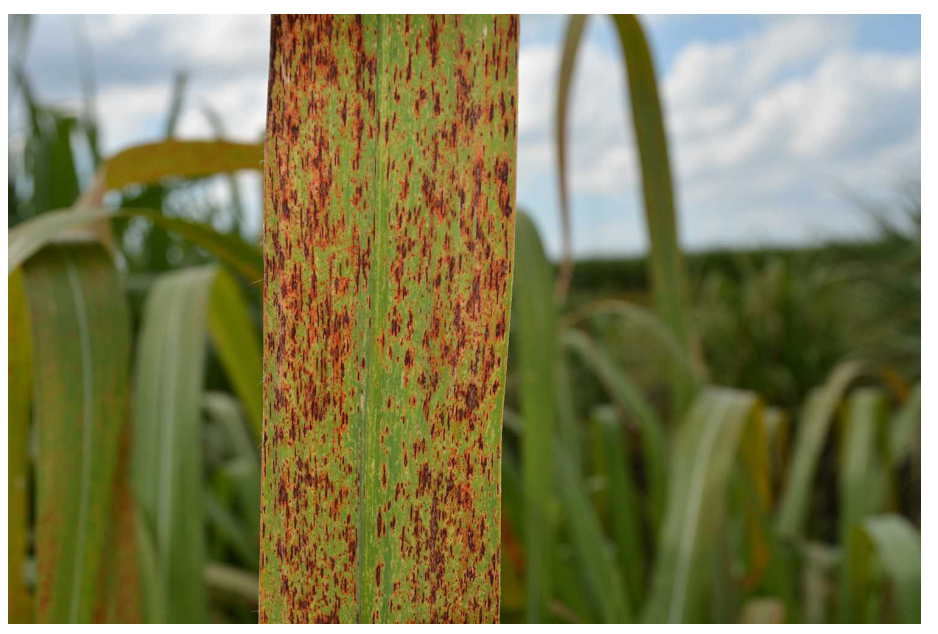

Figure 13. Brown rust symptoms on a sugarcane leaf. Credits: Philippe Rott, UF/IFAS

Eventually, brown rust lesions darken, and the surrounding leaf tissues become necrotic. On highly susceptible 
cultivars, large numbers of pustules may occur on a leaf and coalesce to form large, irregular necrotic areas. Severe rust may even result in premature death of young leaves. These rust infections can cause reductions in both stalk mass and stalk numbers, reducing cane yield (Raid and Comstock 2006).

Relative humidity and cool-to-moderate atmospheric temperatures are the most significant environmental factors in brown rust development. Several hours of leaf surface wetness at a favorable temperature are necessary for successful spore germination, infection, and spread of the disease. While long dew periods and rainfall events both contribute to leaf wetness, rainfall events may not be as favorable for rust development. Heavy rains tend to remove spores from the atmosphere, and spores are ineffective if they land on the soil instead of the leaves. Increased soil moisture also favors rust infection by increasing humidity within the canopy and lengthening the duration of leaf wetness.

In Florida, brown rust is most severe from February to May, when nighttime temperatures are cool to moderate. Brown rust symptoms are more severe in newly planted sugarcane that is three to six months old than in more mature plant cane or ratoon cane of any age (Raid and Comstock 2006). Additionally, brown rust is more severe in sugarcane planted in fields following vegetable rotations than in sugarcane planted in rotation with rice or successively planted. This is generally believed to be the case due to higher soil fertility levels.

Until the first appearance of orange rust in Florida in 2007, brown rust was solely controlled using resistant cultivars. However, with the recent registration of fungicides for sugarcane rust control, the acreage of Florida sugarcane susceptible to brown rust has actually increased. For example, cultivar CP96-1252, which occupied 29\% of the sugarcane acreage in Florida in 2016, is susceptible to brown rust (VanWeelden et al. 2017). This situation is not due to breakdown of disease resistance; it is the result of growers choosing to chemically manage brown rust and orange rust. The latter disease is persistent and requires more fungicide sprays. Cultivation of resistant cultivars should remain the method of choice, because resistance to brown rust has been shown to be a highly heritable trait.

\section{ORANGE RUST}

Until the late 1990s, orange rust was considered a minor disease of sugarcane that occurred primarily in Asia and Australia. This perception changed when the disease became a severe epidemic and caused millions of dollars in losses of cultivar Q124 in Australia (Magarey et al. 2011). The causal agent of orange rust (P. kuehnii) was first observed in Florida sugarcane in July 2007. Shortly after this, orange rust spread throughout the Western Hemisphere cane growing region, including Brazil, which is the world's leading sugar-producing country (Rott et al. 2014b). After the emergence of orange rust in Florida, several sugarcane cultivars (CP80-1743, CP72-2086, CL85-1040, etc.) appeared susceptible to the disease. Fungicides were applied to control orange rust until sustainable host-plant resistance was available in new cultivars. Currently, three major classes of fungicides are used to limit the impact of rust on Florida sugarcane production. These are discussed in the Chemical Management section.

Like brown rust, orange rust only infects the leaf and leaf sheath. It begins as small yellow flecks. Temperatures of $24^{\circ} \mathrm{C}-25^{\circ} \mathrm{C}\left(75^{\circ} \mathrm{F}-77^{\circ} \mathrm{F}\right)$ with leaf wetness durations exceeding 8 hours are favorable for disease progress. Over time, the flecks grow, and spore-producing pustules develop on susceptible cultivars (Figure 14) (Ryan and Egan 1989). Orange rust pustules appear light cinnamon brown to orange rather than dark brown due to lighter spore pigmentation. These pustules are typically oval with a length of $2-10 \mathrm{~mm}$ and a width of 1-3 mm. Pustules are most prevalent on the lower leaf surface and frequently form large blotches on the leaf blade, causing tissue death. Orange rust also occurs lower in the canopy than brown rust, which aggressively infects the younger, upper leaf canopy.

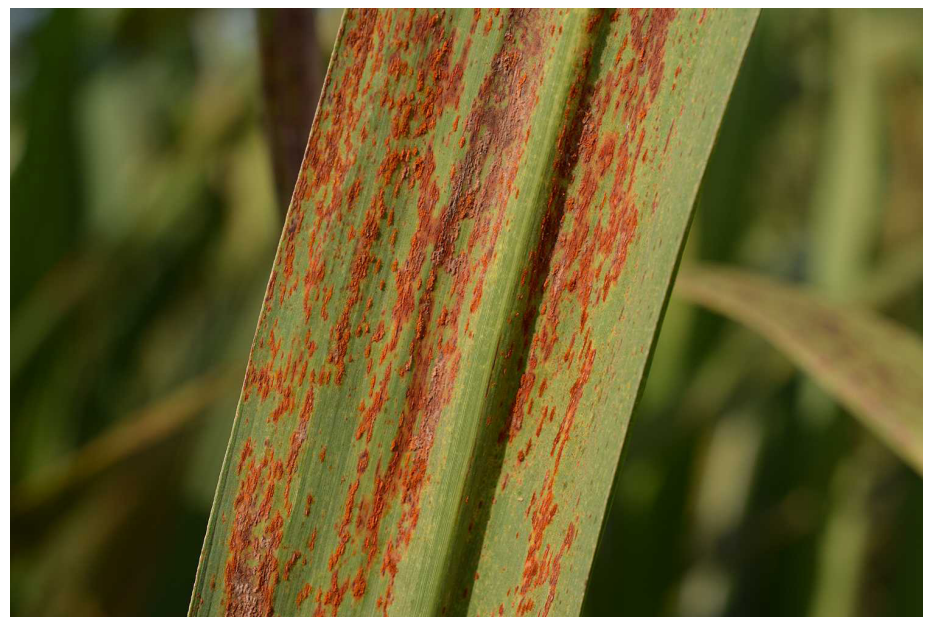

Figure 14. Orange rust pustules on the lower side of a sugarcane leaf. Credits: Philippe Rott, UF/IFAS

Orange rust can also cause significant yield reductions.

Trials using fungicides on a susceptible cultivar to provide a near disease-free check for comparison have demonstrated reductions in sugar per acre of 43-53\% (Raid et al. 2011). CP80-1743, which occupied nearly $25 \%$ of the total area 
when the initial outbreak of orange rust occurred in 2007, was significantly affected. This cultivar has since been withdrawn from commercial production and replaced by less susceptible cultivars. However, several other cultivars, such as CP88-1762 and CP89-2143, which were initially classified as resistant to orange rust based on an absence of disease symptoms during 2007 and 2008 field surveys, rapidly showed disease symptoms following an increase in area planted. Similarly, CP89-2143 was rated resistant during the 2010 crop season, but was rated susceptible two years later (BASF and Glades Crop Care, unpublished data). These breakdowns of rust resistance were attributed to the appearance of new strains of the pathogen (Rott et al. 2016; Sanjel et al. 2016). Occurring over a longer period of time and later in the growing season than brown rust, orange rust may reduce stalk sucrose content as well as stalk populations and biomass.

Mature sugarcane appears as susceptible to orange rust as young cane. Plant cane and ratoon crops appear to be equally susceptible to the disease. Although the disease cycle for orange rust is similar to that of brown rust, the two diseases differ in terms of the environmental conditions that favor their development. Considered a "warm temperature" disease, orange rust may persist through the hot summer months and into fall, while brown rust typically declines rapidly in June with the onset of hot summer temperatures.

Cultivars may vary widely in susceptibility to orange rust, and host plant resistance is an important management tool. However, varietal resistance to brown rust does not simultaneously confer resistance to orange rust, and vice versa. For example, CP96-1252 is susceptible to brown rust but highly resistant to orange rust. CP88-1762 and CP89-2143 are resistant to brown rust but susceptible to orange rust. In 2016, about $40 \%$ of the overall sugarcane area in Florida contained cultivars that were susceptible or moderately susceptible to orange rust, including CP01-1372, CP88-1762, CP88-4730, CP00-1001, and CP80-1743 (VanWeelden et al. 2017). In recent years, new cultivars with resistance to orange rust have been released. This should result in fewer fungicide applications to control orange rust in the coming years.

\section{YELLOW LEAF}

Yellow leaf (previously known as yellow leaf syndrome or YLS) was first recognized in Florida in 1993, but the disease had most likely been present in the state for several years (Comstock, Irvine, and Miller 1994; Rott et al. 2016). Symptoms included a bright yellow coloration on the lower side of the leaf midrib and necrosis starting from the leaf tip and spreading outward from the leaf midrib (Figure 15). Symptoms were most evident on mature sugarcane stalks. In 1997, incidence of Sugarcane yellow leaf virus (SCYLV) exceeded $90 \%$ in a majority of Florida's commercial sugarcane cultivars, and 43 of 46 parental clones used in the crossing program for Florida tested positive for the virus (Comstock et al. 1998). These high levels of sugarcane infection suggested that resistance to yellow leaf was rare in the Florida sugarcane germplasm.

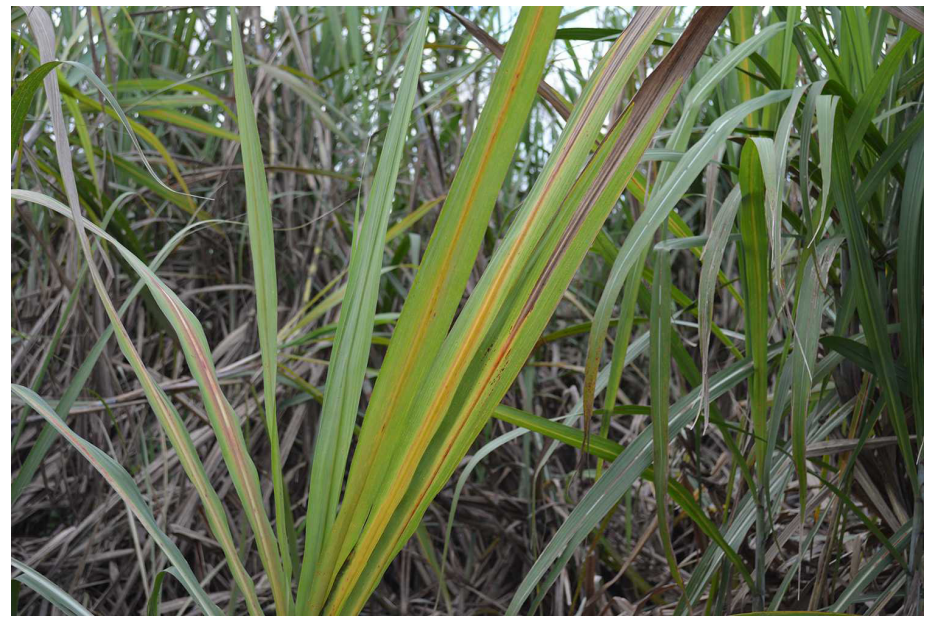

Figure 15. Symptoms of sugarcane yellow leaf: yellow coloration of the lower side of leaf midribs.

Credits: Philippe Rott, UF/IFAS

Most infected sugarcane cultivars do not display symptoms, and identification of the disease requires the use of molecular detection techniques in the laboratory. Therefore, visual symptoms are not a reliable means of resistance screening or detection of the pathogen in the field. Yield loss experiments conducted from 2001 to 2004 showed that yield parameters (such as number of stalks, stalk weight, and sucrose per plot) were significantly higher in SCYLVfree plots than in virus-infected plots (Comstock and Miller 2004). On average, across five cultivars, stalk weights were reduced by $11 \%$ in diseased plots versus healthy plots.

SCYLV is spread from plant to plant by the sugarcane aphid (M. sacchari) and from a contaminated field to a new field through infected stalk cuttings. An alternative control measure was investigated in Florida because sources of host plant resistance were limited, and mechanical inoculation of sugarcane with SCYLV was not feasible for rapid screening of breeding material (Rott et al. 2016). Virus-free, tissue-cultured plantlets were produced using Kleentek ${ }^{\circledR}$ technology. These plantlets were used to establish diseasefree nurseries for commercial sales starting in 2000.

Sugarcane plants produced in these nurseries were used to propagate seed cane for the subsequent establishment of 
new commercial fields. However, recent surveys revealed that the use of virus-free planting material is only partially effective in controlling yellow leaf because material propagated in nurseries or commercial fields becomes re-infected by the virus within a few years (Rott et al., unpublished data). Current efforts are focused on importing resistant germplasm, breeding new cultivars for resistance or tolerance to the virus (whereby the virus could be present in the plant, but yield potential is not affected), and reducing the number of nursery cycles for production of healthy, virusfree planting material.

\section{Non-Chemical Management of Disease Pests in Florida Sugarcane Crops}

Planting resistant cultivars of sugarcane is the preferred method for controlling most sugarcane diseases. In this regard, the Florida sugarcane breeding program has had success in breeding for resistance to diseases such as brown rust, leaf scald, mosaic, pokkah boeng, ratoon stunting, and smut. Additionally, it is highly recommended that growers use planting material expanded from clean seed cane nurseries, where seed cane has been hot water-treated or developed from tissue culture (Kleentek ${ }^{\circledR}$ ). Crop rotation with rice or vegetables may likewise play a role in reducing the impact of these diseases.

Unfortunately, many of the current sugarcane cultivars that are commercially grown in Florida are not resistant to orange rust (VanWeelden et al. 2017). Shifts to planting resistant sugarcane cultivars will have to occur. New sugarcane clones are being screened for orange rust resistance within the $\mathrm{CP}$ sugarcane cultivar development program at Canal Point. This will ensure that resistant clones are released in the future. Presently, the number of resistant cultivars is limited, and the supply of seed cane of resistant cultivars is insufficient for all new plantings. To complicate matters, new strains of the rust pathogen (races) appear to arise as new cultivars are expanded to large acreages. Thus, the quest to maintain host-plant resistance may be short-lived.

The development of durable resistance is of vital interest. It may be prudent for growers to diversify their cultivar holdings, allowing no cultivar to occupy more than $20-25 \%$ of the total acreage to prevent catastrophic losses should a previously resistant cultivar become susceptible to a new rust pathogen variant or race. Such diversification is an effective means of lowering risk of yield loss and reducing the likelihood of evolution of a new race of rust. Varietal diversification may also play an important role in holding down overall area-wide disease pressure, reducing the natural selection pressure for one particular rust variant. A general rule of epidemiology suggests that varietal diversification may assist in preserving the durability of host-plant resistance in currently resistant cultivars (Raid and Comstock 2006).

Soil factors associated with high levels of rust infection on sugarcane include low soil $\mathrm{pH}$ and/or high fertility. Growing susceptible cultivars in areas with these soil conditions should be avoided. Sugarcane grown in fields with recent applications of nutrient amendments is typically prone to rust. If possible, cultivars with durable rust resistance should be planted in these fields (Raid and Comstock 2006). Additional control strategies, such as planting date optimization, modification of crop nutrient inputs, and use of a disease prediction system, are currently being investigated.

\section{Chemical Management of Disease Pests in Florida Sugarcane Crops}

Since 2008, a number of fungicides have been registered for use in managing orange and brown rust, and additional registrations are anticipated (Rott et al. 2014b). Currently, two strobilurin class fungicides (FRAC group 11) are registered for use: pyraclostrobin and azoxystrobin. Two triazole class fungicides (FRAC group 3), metconazole and propiconazole, have also been approved for use. A third class of carboxamides (FRAC group 7) was more recently approved. Three pre-mixtures of the aforementioned classes are also registered. Of the three classes, the strobilurins have displayed the best efficacy and should serve as the basis for any chemical control program. However, to minimize the risk of fungicide resistance, no more than two sequential applications of this class should be made. Strobilurins should be rotated with one of the triazole or carboxamide fungicides.

Fungicides may assist in reducing yield losses, and their effectiveness is determined by the number and frequency of applications. However, timing should also be considered and optimized to maximize returns in commercial fields. Due to the long cropping season, it is generally recommended that rust fungicide applications be made at 3- to 4-week intervals. The highest labeled rate should be used, particularly if applications are made at 4-week intervals. Addition of a nonionic surfactant is recommended. In Florida, fungicide applications are recommended only for rust-susceptible cultivars. For brown rust, applications should begin in early spring and typically end by May. Frequently, one or two applications are sufficient. For orange rust, applications should begin in late spring to early 
summer and extend into fall only if conditions are favorable for disease persistence. Programs initiated in the fall after severe infection have not proven to be effective or economically beneficial.

\section{Weed Management in Florida Sugarcane Fields}

Weed management, or the combination of techniques for prevention, eradication, and control of weeds in sugarcane, is most critical early in the season, prior to canopy closure over the row middles. Poor weed management can lead to heavy weed infestation and result in significant sugarcane yield loss or total crop failure. Weeds, particularly vines, can interfere with harvesting operations by increasing the need for frequent removal from harvesters as well as repair expenses. Additionally, weeds that mature and produce seed become sources of seed-bank replenishment and re-infestation and exacerbate weed management problems for years to come. The most important weed pests in Florida sugarcane production are fall panicum (Panicum dichotomiflorum), bermudagrass (Cynodon dactylon), yellow and purple nutsedge (Cyperus esculentus and C. rotundus), common lambsquarters (Chenopodium album), and pigweeds (Amaranthus spp.) (Odero and Dusky 2014; Odero et al. 2014; Webster 2012). Other weed species that can affect Florida sugarcane include goosegrass (Eleusine indica), crowfootgrass (Dactyloctenium aegyptium), crabgrasses (Digitaria spp.), napiergrass (Pennisetum purpureum), Columbus grass (Sorghum almum), torpedograss (Panicum repens), common purslane (Portulaca oleracea), American black nightshade (Solanum americanum), common ragweed (Ambrosia artemisiifolia), ragweed parthenium (Parthenium hysterophorus), morning glories (Ipomoea spp.), coffee senna (Senna occidentalis), and sicklepod (Senna obtusifolia). Ragweed parthenium commonly associated with non-crop areas is presently encroaching and becoming a weed in sugarcane fields.

\section{Common Weeds in Florida Sugarcane Crops}

\section{FALL PANICUM}

Fall panicum (Panicum dichotomiflorum) is the most important annual grass weed in Florida sugarcane. It primarily emerges between September and May, but seed germination can occur almost year-round in the sugarcane production region of Florida. This period coincides with planting, harvesting, and early-season growth and development of sugarcane.
Fall panicum is a small-seeded grass. Seedlings have hairs on the lower surface of the leaf blades (Figure 16) that disappear with maturity. The growth habit of fall panicum can range from erect to sprawling with formation of large, loose tufts depending on competition (Odero et al. 2014). Fall panicum has a waxy-looking stem that is bent and without rooting at the nodes. It typically reaches a height of 1.5-4 feet, but it has also been reported to reach heights of more than 7 feet (Odero et al. 2014). The leaf sheath and blades are smooth; however, some hairy biotypes associated with Florida sugarcane exist (Figure 17). The species is sensitive to shading (Vengris and Damon, Jr. 1976) and is usually not found in sugarcane once canopy closure occurs.

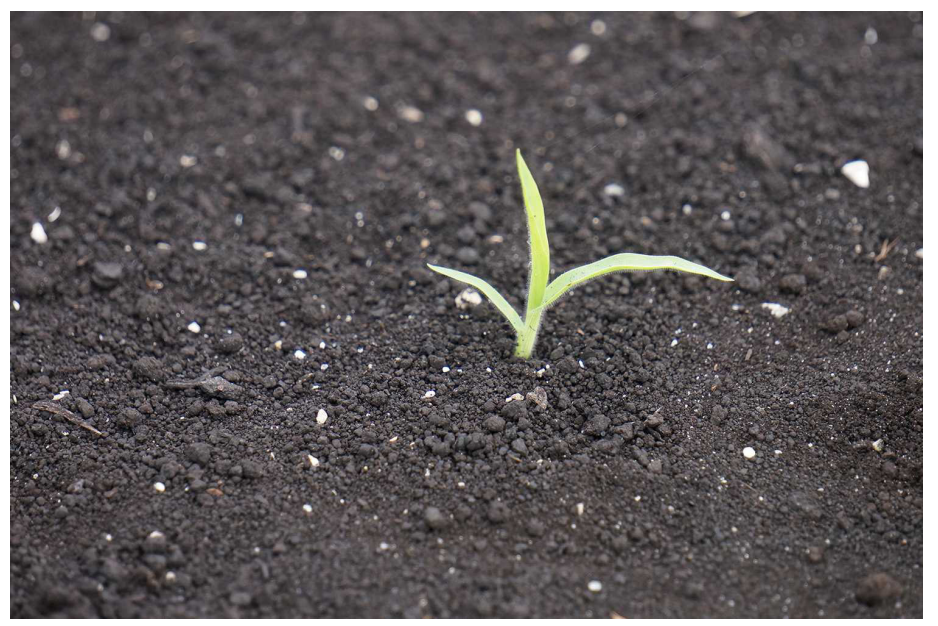

Figure 16. Fall panicum seedling with hairs on the lower surface of the leaf blade.

Credits: Calvin Odero, UF/IFAS

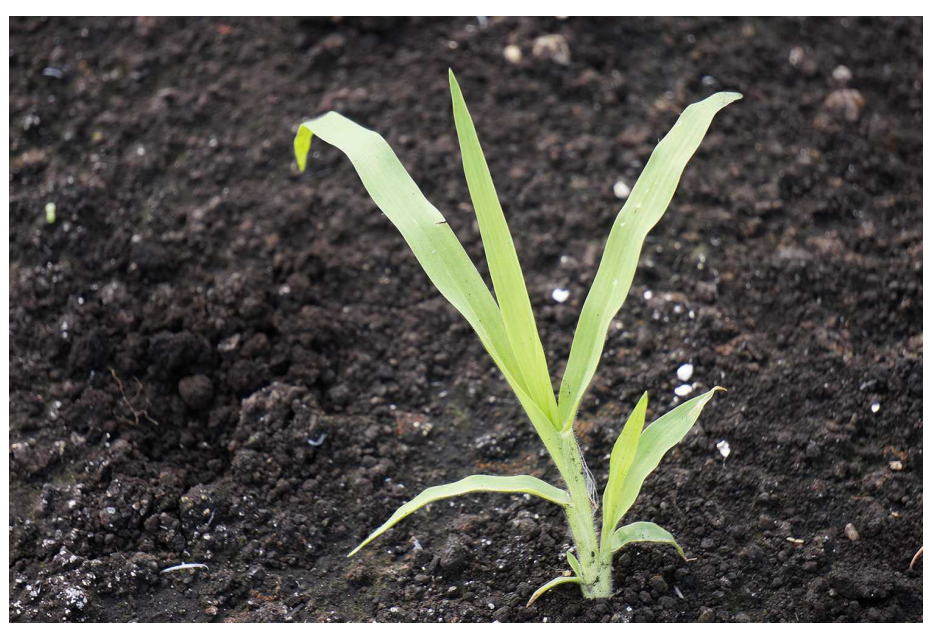

Figure 17. Fall panicum with hairs on the lower surface of the plant. Credits: Calvin Odero, UF/IFAS

\section{BERMUDAGRASS}

Bermudagrass (Cynodon dactylon) is the most problematic perennial grass weed in Florida sugarcane. It is a wiry, low-growing or prostrate plant with stems arising from aboveground stolons and belowground rhizomes (Figure 18), and rooting at the nodes (Figure 19). Propagation 
occurs primarily through rhizomes and stolons and less commonly by seed. Bermudagrass is most competitive with sugarcane early in the season before canopy closure because it is not shade-tolerant (Horowitz 1972). It interferes with sugarcane by shading emerging shoots and reducing tiller formation and survival. Once established, it is difficult to manage. It is only sufficiently controlled during the sugarcane fallow period.

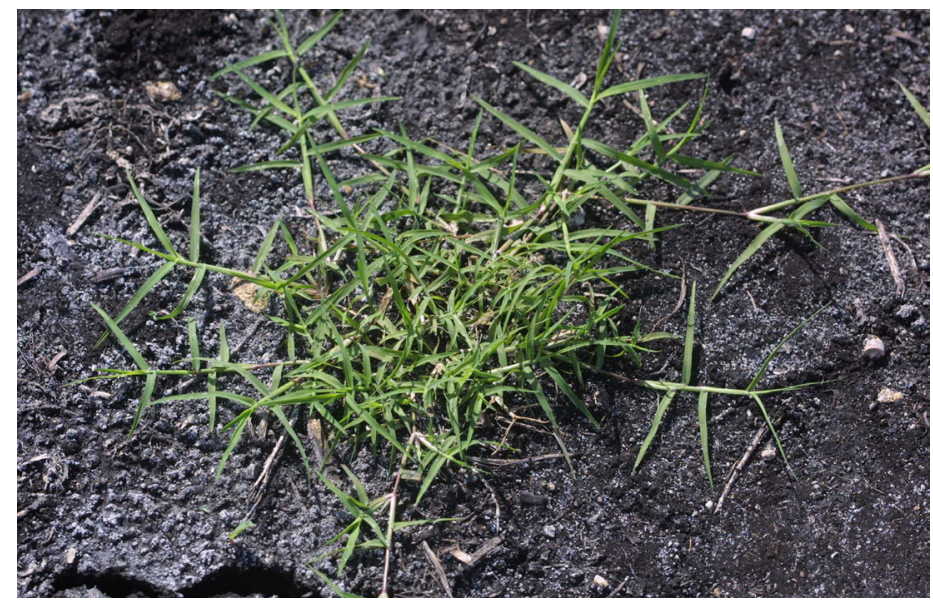

Figure 18. Prostrate bermudagrass.

Credits: Calvin Odero, UF/IFAS

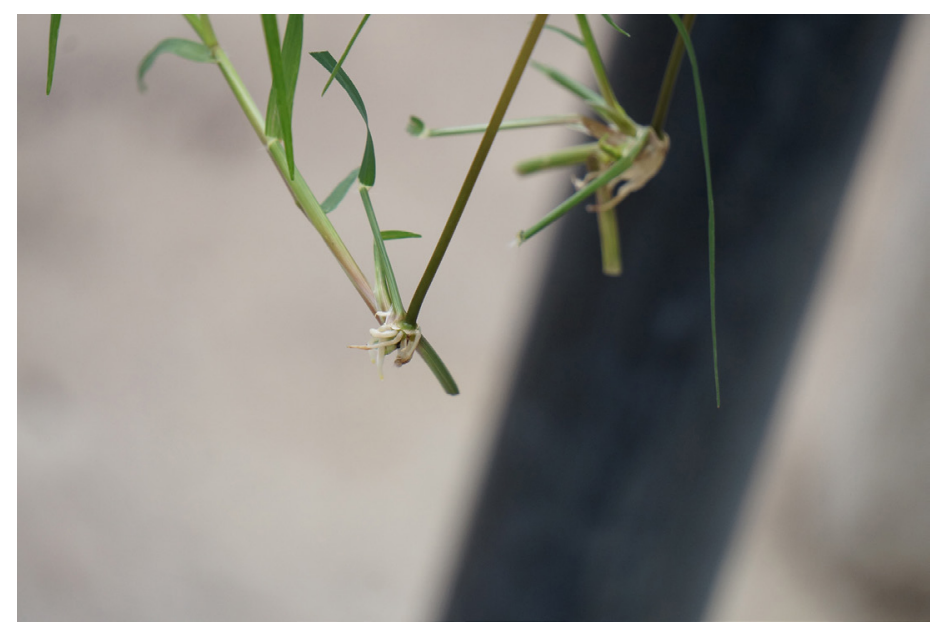

Figure 19. Bermudagrass rooting at the node.

Credits: Calvin Odero, UF/IFAS

\section{NUTSEDGES}

Yellow nutsedge (Cyperus esculentus) and purple nutsedge (C. rotundus) are important weeds of Florida sugarcane, with yellow nutsedge being the most prevalent. Both are perennial plants with three-angled stems and long grass-like leaves. However, they have different leaf tip shapes, inflorescence, and tubers. Leaves of yellow nutsedge gradually taper to a sharp point, while purple nutsedge leaves abruptly taper to a sharp point (Figure 20). Yellow nutsedge has yellowish-brown flowers that may produce some seed (Figure 21). However, propagation is primarily by smooth, round tubers at the end of rhizomes (Figure 22).
Low nitrogen, short photoperiod, and high temperature $\left(27-33^{\circ} \mathrm{C}\right.$, or $\left.80-91^{\circ} \mathrm{F}\right)$ are favorable to tuber production (Garg, Bendixen, and Anderson 1967). Both nutsedges are tolerant to high soil moisture but intolerant to shade. This implies that a rapidly developing sugarcane canopy can suppress them. However, shading does not eliminate yellow nutsedge tuber formation because the plant can efficiently divert dry matter into tubers (Patterson 1995; Stoller and Sweet 1987). Purple nutsedge has reddish purple or reddish brown flowers that sometimes develop into mature viable seeds (Figure 21). However, propagation is primarily from rough, irregularly shaped tubers connected in chains along the length of rhizomes (Figure 22). Purple nutsedge can survive in a wide range of environmental conditions, including harsh ones, making it especially difficult to control. It grows well in nearly all soil types and over a range of soil moistures, soil $\mathrm{pH}$, and elevations. Purple nutsedge is also able to survive extremely high temperatures compared to yellow nutsedge (Stoller and Sweet 1987).

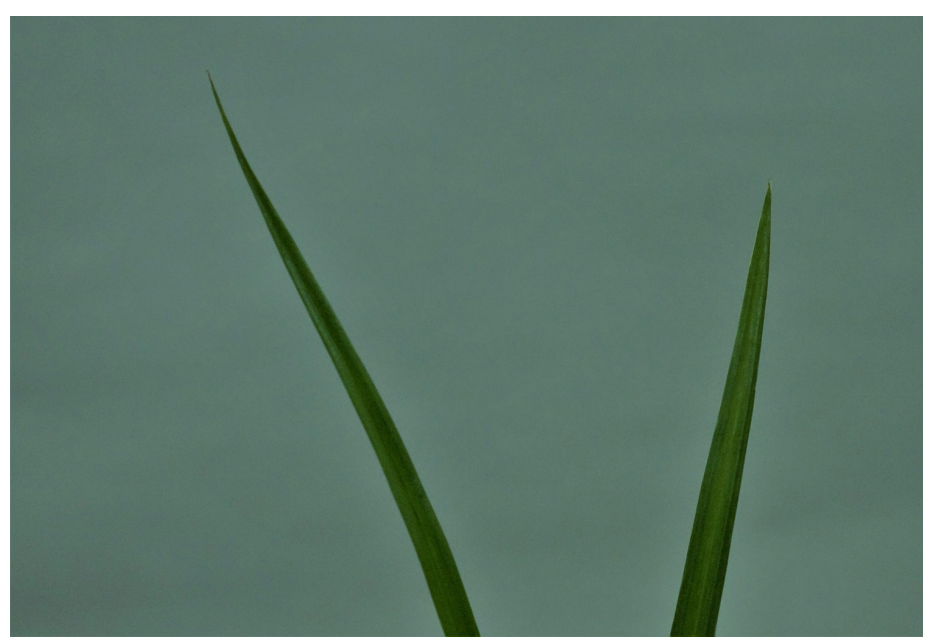

Figure 20. Leaf tips of yellow and purple nutsedge. Note the long, tapered yellow nutsedge leaf tip (left) in contrast to the abrupt taper of the purple nutsedge leaf tip (right).

Credits: Calvin Odero, UF/IFAS

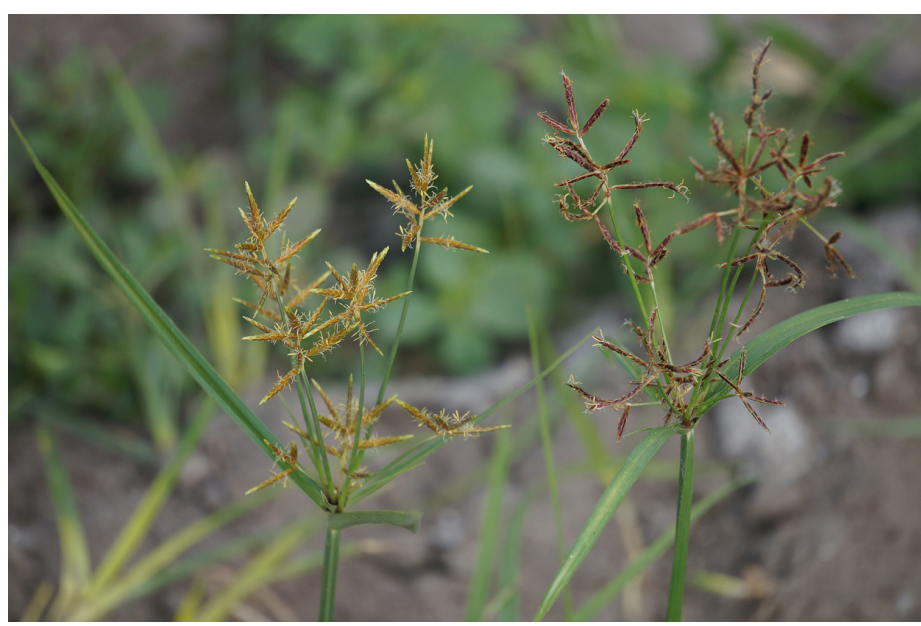

Figure 21. Yellow (left) and purple (right) nutsedge flowers.

Credits: Calvin Odero, UF/IFAS 


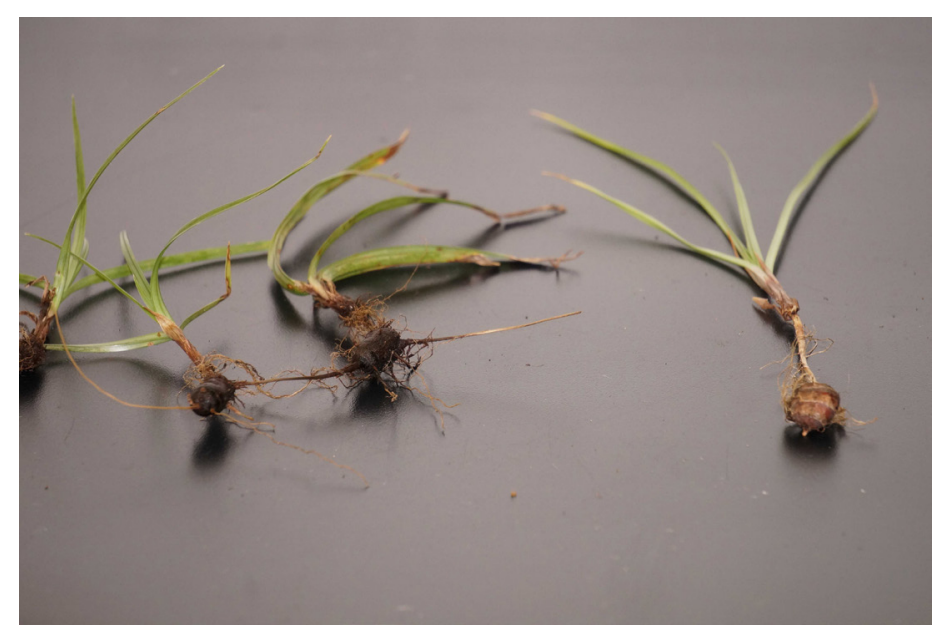

Figure 22. Irregularly shaped purple nutsedge tubers connected in a chain along the length of the rhizome (left) and a round yellow nutsedge tuber at the end of the rhizome (right).

Credits: Calvin Odero, UF/IFAS

\section{COMMON LAMBSQUARTERS}

Common lambsquarters (Chenopodium album) is an annual broadleaf weed commonly found in Florida sugarcane during cooler months in the fall and spring. It has large seed-bank reserves that can remain viable in the soil for several years (Roberts and Feast 1973), enabling it to persist in cultivated fields from year to year. Seedlings have egg-shaped to triangular leaves with mealy gray powdery coating (Figure 23). Common lambsquarters has an erect, grooved stem with a greenish or reddish color and a height of 4 inches to 6 feet (Figure 24). The leaves are alternate. A mealy gray, powdery coating covers younger leaves in particular. Common lambsquarters is a small-seeded plant. Competitiveness of common lambsquarters with sugarcane is determined by its density and relative time of both plants' emergence.

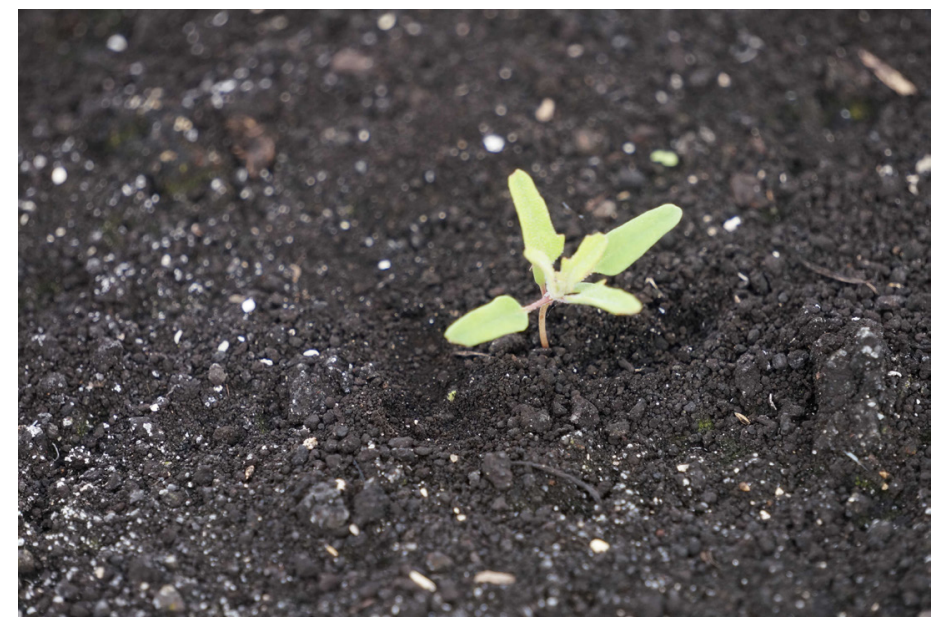

Figure 23. Common lambsquarters seedling.

Credits: Calvin Odero, UF/IFAS

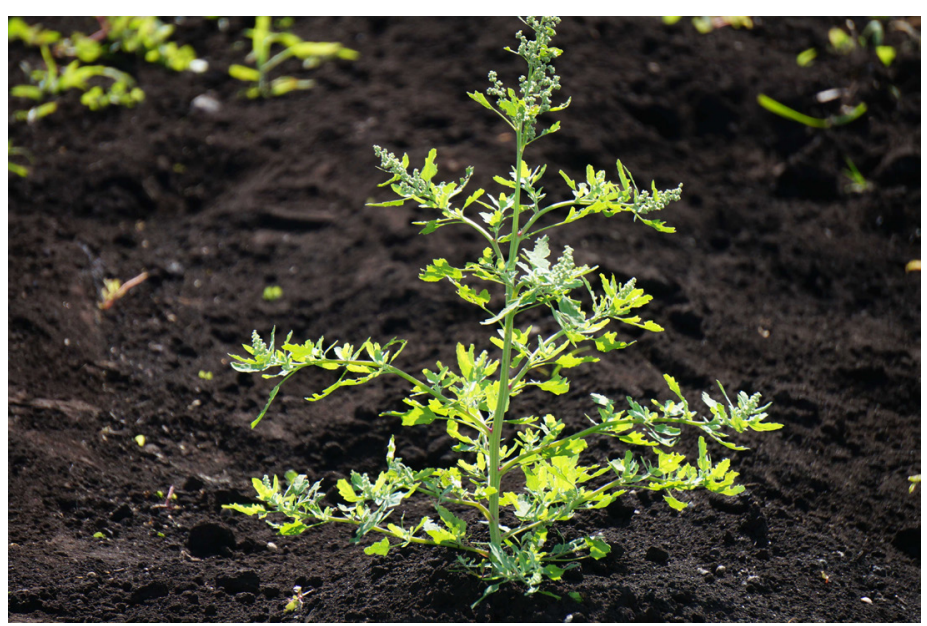

Figure 24. Mature common lambsquarters.

Credits: Calvin Odero, UF/IFAS

\section{PIGWEEDS}

Spiny amaranth (Amaranthus spinosus) is the most prevalent pigweed in Florida sugarcane. Other common species include smooth pigweed (A. hybridus) and livid amaranth (A. lividus). Pigweeds are summer annuals with well-developed pinkish or reddish shallow taproots. They are commonly found year-round in the sugarcane production region of Florida. Spiny amaranth and smooth pigweed are both erect and branched, reaching up to 8 feet in height, while livid amaranth is prostrate with ascending or erect stems up to 3 feet long (Figure 25). Smooth pigweed is densely hairy with short hair on the upper stem region, while spiny amaranth has a pair of sharp, stiff spines at the base of most leaves (Figure 26). They reproduce by seed and are very competitive with young sugarcane. They have an aggressive growth habit even under dry conditions associated with the early sugarcane growing season in Florida. Pigweeds are small-seeded plants.

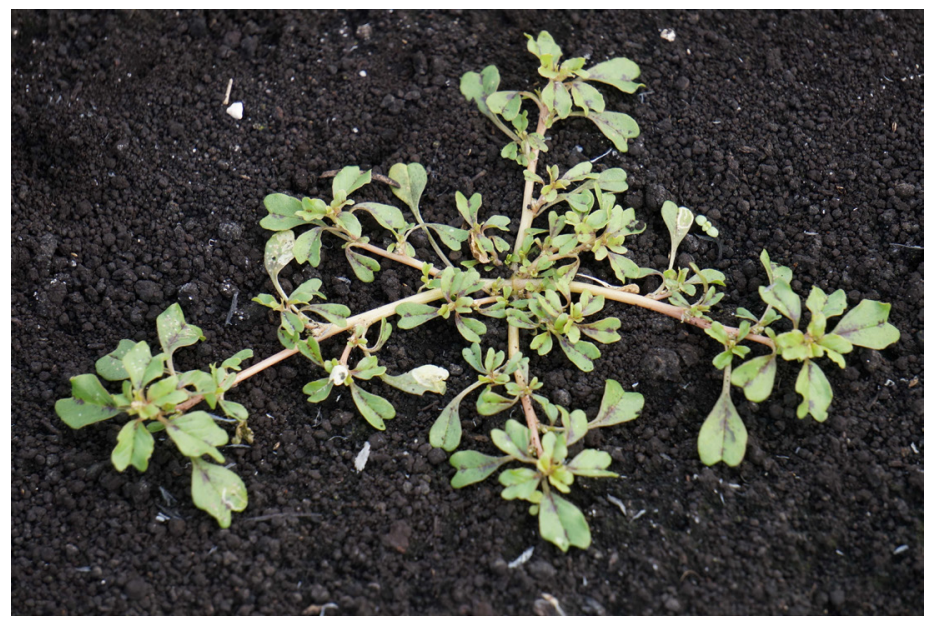

Figure 25. Prostrate livid amaranth.

Credits: Calvin Odero, UF/IFAS 


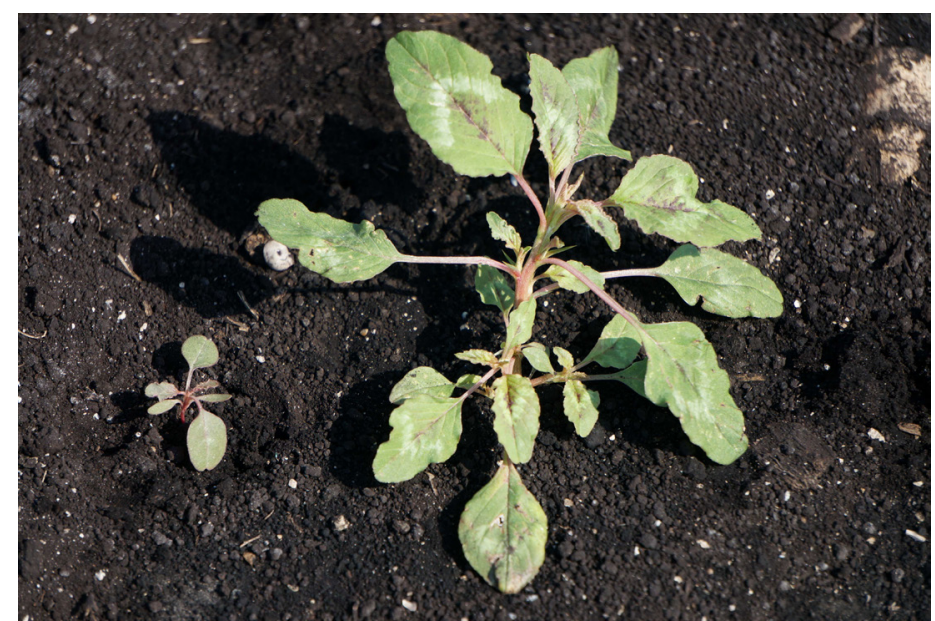

Figure 26. Spiny amaranth seedling (left) and mature plant (right) with spines at the base of leaves.

Credits: Calvin Odero, UF/IFAS

\section{Non-Chemical Weed Management in Florida Sugarcane Crops CROP ROTATION}

Crop rotation is an important component of weed management in sugarcane. Crop rotation helps to disrupt weed life cycles and can effectively reduce weed populations when combined with other weed control strategies. Traditionally, the fallow period between final ratoon harvest and replanting of sugarcane has effectively been used to manage troublesome weed populations using mechanical cultivation, crop rotation, and flooding. Sugarcane is rotated with vegetables or rice, or the fields are left fallow. Flooding in fallow fields can aid in weed control through the development of an anaerobic environment that impairs germination of weed seeds and seedling growth. Remember to take precautions when rotating with grass crops (sweet corn and rice) that exacerbate grass weed problems.

\section{CROP COMPETITION}

The extent of sugarcane yield loss by weeds depends on the cultivar used. Cultivars that emerge rapidly after planting with profuse tillering and faster canopy closure will be very competitive against weeds. For instance, sprawling cultivars with high tiller formation and rapid canopy closure will be more competitive than erect cultivars with slower canopy closure. Competitive cultivars are important, especially in Florida, where wider row spacing of 5 feet requires sufficient canopy closure early enough to suppress weeds. Good ratooning cultivars are also important to ensure a competitive edge against weeds. However, loss of sugarcane stand in ratoon crops due to rodent, pest, or harvest damage can create open spaces in the sugarcane canopy under which weeds proliferate. Therefore, sugarcane stands must be maximized throughout the entire crop cycle to assist weed management efforts (Odero and Dusky 2014).

\section{MECHANICAL CULTIVATION}

Mechanical cultivation is used to control emerged weeds in sugarcane using different tillage equipment. Cultivation controls weeds by burying seedlings and small annual weeds in soil and uprooting or severing roots, resulting in death by desiccation. Take precautions to avoid severing sugarcane roots as well during this process. Cultivation does not control weeds growing near cane stalks (or between cane plants within the planted row), so there may still be a need for a banded herbicide program for the cane rows. A height differential must be established between sugarcane and the weeds to ensure that sugarcane has an early competitive advantage for light interception (Odero and Dusky 2014). Mechanical cultivation is only effective when sugarcane is growing taller than competing weeds (Odero and Dusky 2014). Cultivation when weeds are not present is not recommended. This may encourage germination of weed seeds by bringing them up in the soil profile to the zone conducive to germination or by removing the layer of herbicide when soil-applied herbicides are used. For ratoon sugarcane, mechanical cultivators must be able to cut through surface debris and thoroughly mix the soil (Odero and Dusky 2014).

\section{Chemical Weed Management in Florida Sugarcane Crops}

Herbicides are a critical component for weed management in Florida sugarcane. They are applied pre-plant (before sugarcane planting), pre-emergence (after planting and before sugarcane emergence), or post-emergence (after both sugarcane and weeds have emerged) (Figure 27). In sugarcane, herbicides can be banded over the row, broadcasted over the entire field, or directed around the base of cane stalks away from leaves. Spot treatments of nonselective herbicides are sometimes used for management of isolated patches of perennial grasses (bermudagrass, napiergrass). Depending on the label instructions, post-emergence herbicides can be applied with adjuvants (surfactants, crop oil concentrates, buffering agents, etc.) to improve herbicidal activity or application characteristics. Before you make a decision regarding herbicide use, you must perform proper weed identification and select the herbicide(s) that will provide maximum control of the target weed(s). Predominantly used herbicides in Florida sugarcane include atrazine, metribuzin, ametryn, 2,4-D amine, asulam, pendimethalin, and halosulfuron. Other commonly used herbicides include mesotrione, trifloxysulfuron, dicamba, and glyphosate. Less commonly used 
herbicides include carfentrazone, diuron, diuron + hexazinone, flumioxazin, and paraquat. These herbicides are mainly used in combinations to broaden the weed control spectrum. Label instructions must be followed by law.

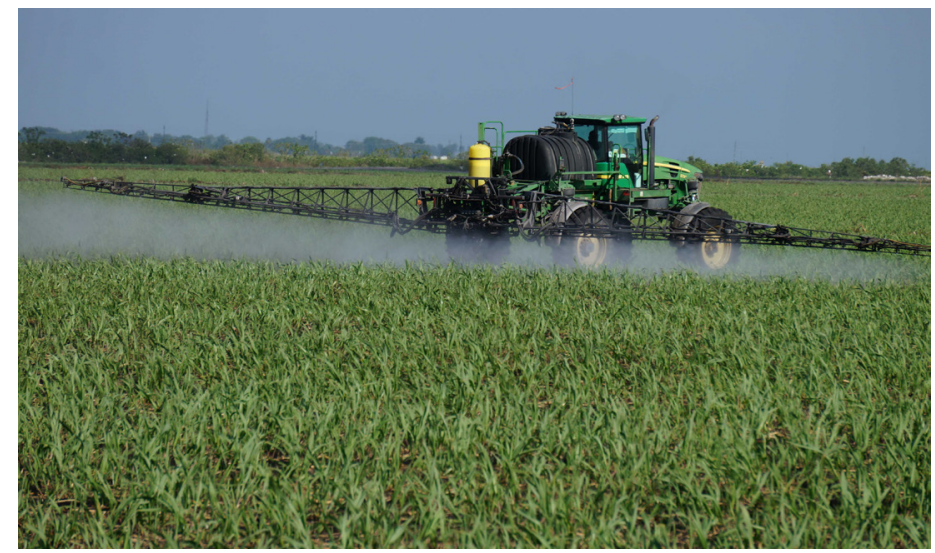

Figure 27. Chemical weed control in sugarcane near Belle Glade, FL. Credits: Calvin Odero, UF/IFAS

\section{ATRAZINE}

Atrazine is a symmetrical triazine herbicide used for pre-emergence or post-emergence control of mainly annual broadleaf weeds and certain grasses. For pre-emergence applications, best results are obtained when rainfall occurs after application. This moves the herbicide to the weed seed germination zone. Atrazine is the most widely used herbicide because of its affordability, flexibility of tank-mixing, and ability to provide residual weed control. However, bacterial adaptation that enhances atrazine degradation has been reported in Florida sugarcane soils, resulting in loss of residual activity (Odero and Shaner 2014; Shaner et al. 2010). It is often tank-mixed with other herbicides to broaden weed control spectrum. Atrazine is a restricted use pesticide and should not be mixed or loaded within 50 feet of canals or any body of water.

\section{METRIBUZIN}

Metribuzin is an asymmetrical triazine herbicide for pre-emergence or post-emergence control of many small-seeded broadleaf weeds and certain grasses. It is not registered for use in sugarcane grown on mineral soils with low soil organic matter content and no significant silt or clay due to leaching concerns. Metribuzin is tank-mixed with other herbicides, especially pendimethalin, to broaden weed control spectrum.

\section{AMETRYN}

Ametryn is a symmetrical triazine herbicide that is mainly used for post-emergence control of small-seeded broadleaf weeds and small grasses due to its limited pre-emergence activity. Because of injury concerns, ametryn should only be applied to emerged weeds at the base of sugarcane under dry, hot, or warm conditions.

\section{2,4-D}

The phenoxy herbicide 2,4-D is mainly used for postemergence broadleaf weed control. It is especially important for vine control later in the season. It can be applied at lay-by and over the top of sugarcane canopy for vines such as morning glories. It can also be used as a pre-plant herbicide in combination with other herbicides. Higher rates of application are used for large or difficult to control weeds, such as alligatorweed (Alternanthera philoxeroides). Exercise caution when using 2,4-D to prevent spray drift to sensitive crops.

\section{ASULAM}

Asulam is a carbamate herbicide used for post-emergence control of annual grasses. Application may be broadcasted, directed, or semi-directed. The activity of asulam is slow and can take up to 4 weeks to provide control, depending on the grass size and prevailing environmental conditions. It is usually tank-mixed with trifloxysulfuron for improved efficacy on grasses, particularly fall panicum.

\section{PENDIMETHALIN}

Pendimethalin is a dinitroaniline herbicide for pre-emergence control of primarily annual grasses. It is applied at the time of planting or ratooning, prior to weed emergence. It is often tank-mixed with metribuzin or atrazine to enhance broadleaf weed control. Rainfall, irrigation, or mechanical incorporation into the soil within 7 days of application is useful to achieve the best efficacy.

\section{HALOSULFURON}

Halosulfuron is a sulfonylurea herbicide used for control of purple and yellow nutsedge, as well as some broadleaf weed species. It can be applied at any stage of sugarcane growth before canopy closure.

\section{Nematode Management in Florida Sugarcane Crops}

Plant-parasitic nematodes are microscopic roundworms found in soil. Ectoparasitic nematodes feed on sugarcane from the exterior of the root, while endoparasitic nematodes enter the plant tissue to feed from within. General symptoms of nematode damage to sugarcane plants include stunting, premature wilting, leaf yellowing, and related symptoms characteristic of nutrient deficiencies. Stunting and poor stand development tend to occur in patches throughout the field as a result of the irregular distribution 
of nematodes within the soil. Ratoon cane is generally most susceptible to damage from nematodes (Crow 2012).

Most species of plant-parasitic nematodes favor mineralsoil conditions and are rarely a problem on organic soils. However, sugarcane grown in mineral soil areas has the potential for dramatic yield losses from nematodes (Crow 2012).

\section{Nematode Pests in Florida Sugarcane}

\section{Crops}

Sting nematode (Belonolaimus longicaudatus), an ectoparasite, is the most damaging nematode to sugarcane in Florida. Stubby-root (Trichodorus and Paratrichodorus spp.), ring (Criconemoides and related genera), and stunt (Tylenchorhynchus and Quinisulcius spp.) nematodes are other ectoparasites that may damage sugarcane and are common in Florida. Endoparasites that may damage sugarcane in Florida are lesion (Pratylenchus zeae), lance (Hoplolaimus spp.), and root-knot (Meloidogyne spp.) nematodes.

\section{Non-Chemical Management of Nematodes in Florida Sugarcane Crops CROP ROTATION}

Rotation with flooded rice crops can reduce populations of plant-parasitic nematodes. Many of the nematodes that feed on sugarcane can also feed on rice under dry conditions. However, rice is normally grown in standing water, and most nematodes cannot survive the flooded conditions (Crow 2012).

\section{FLOODING}

Flooding can be an effective management strategy for nematode control in sugarcane. The area should be flooded for a 4-week period, drained and left dry for 2 weeks, and flooded again for 4 weeks (Crow 2012). This practice is difficult on mineral soils, where nematodes are most prevalent.

\section{SOIL AMENDMENT}

Sediment collected in the sugarcane juice clarification process is called filter cake, cachaza, or mill mud. Soil amendment with this mill by-product has been shown to reduce populations of plant-parasitic nematodes on sugarcane. Filter cake can be added as an amendment to mineral soil areas to reduce nematode damage. The addition of organic matter, including sugarcane filter cake, to mineral soil can also improve plant tolerance and make nematode damage less severe (Crow 2012).

\section{Chemical Management of Nematodes in Florida Sugarcane Crops}

There are currently no efficacious nematicides labeled for sugarcane in Florida.

\section{Vertebrate Management in Florida Sugarcane Fields}

Several rat species feed on sugarcane plants and can occasionally cause measurable economic loss. Zinc phosphide is registered to control vertebrates in sugarcane fields in Florida. Rodenticides are applied on the margins of sugarcane fields, but are used on less than $1 \%$ of the area planted to sugarcane in Florida.

\section{References}

Baucum, L. E. and R. W. Rice. 2009. An Overview of Florida Sugarcane. SS-AGR-232. Gainesville: University of Florida Institute of Food and Agricultural Sciences. http://ufdc.ufl. edu/IR00003414/00001

Cherry, R. H. 2012. White Grubs in Florida Sugarcane. ENY-664. Gainesville: University of Florida Institute of Food and Agricultural Sciences. http://edis.ifas.ufl.edu/ sc012

Cherry, R. H. 2017. Wireworms in Florida Sugarcane. ENY665. Gainesville: University of Florida Institute of Food and Agricultural Sciences. http://edis.ifas.ufl.edu/sc013

Cherry, R. H., G. S. Nuessly, and H. S. Sandhu. 2015. Insect Management in Sugarcane. ENY-406. Gainesville: University of Florida Institute of Food and Agricultural Sciences. http://edis.ifas.ufl.edu/ig065

Cherry, R. H., J. M. McCray, and H. S. Sandhu. 2017. "Changes in the relative abundance of soil-dwelling insect pests in sugarcane grown in Florida." Journal of Entomological Science 52(2): 169-176. http://gaentsoc.org/doi/ abs/10.18474/JES16-33.1? code=gens

Comstock, J. C. and J. D. Miller. 2004. "Yield comparisons: Disease-free tissue-culture versus bud-propagated sugarcane plants and healthy versus yellow leaf infected plants." Journal of the American Society of Sugar Cane Technologists 24: 31-40. https://assct.org/journal/JASSCT\%20PDF\%20 Files/volume\%2024/A03-01\%20Comstock\%20final.pdf

Comstock, J. C., J. Shine, Jr., and R. N. Raid. 1992. "Effect of rust on sugarcane growth and biomass." Plant Disease 76: 175-177. http://www.apsnet.org/publications/ 
PlantDisease/BackIssues/Documents/1992Articles/PlantDisease76n02_175.pdf

Comstock, J. C., J. E. Irvine, and J. D. Miller. 1994. "Yellow leaf syndrome appears on the United States mainland." Sugar Journal 56: 33-35.

Comstock, J. C., M. S. Irey, B. E. L. Lockhart, and Z. K. Wang. 1998. "Incidence of yellow leaf syndrome in CP cultivars based on polymerase chain reaction and serological techniques." Sugar Cane 4: 21-25. https://www.ars.usda. gov/research/publications/publication/?seqNo115 $=90625$

Comstock, J. C., N. C. Glynn, and R. W. Davidson. 2010. "Sugarcane rusts in Florida." Proceedings of the International Society of Sugar Cane Technologists 27: 9 pp. http://www. issct.org/pdf/proceedings/2010/2010\%20Comstock,\%20 SUGARCANE\%20RUSTS\%20IN\%20FLORIDA.pdf

Comstock, J. C., H. S. Sandhu, and D. C. Odero. 2015. Sugarcane Yellow Leaf Disease. SS-AGR-256. Gainesville: University of Florida Institute of Food and Agricultural Sciences. http://edis.ifas.ufl.edu/sc074

Crow, W. T. 2012. Plant-Parasitic Nematodes on Sugarcane in Florida. ENY-053. Gainesville: University of Florida Institute of Food and Agricultural Sciences. http://ufdc.ufl. edu/IR00007768/00001

Egan, B. T. 1964. "Rusts." In Sugar-cane diseases of the world, edited by C. G. Hughes, E. V. Abbott, and C. A. Wismer. 61-68. New York, NY: Elsevier Publishing Co. https://www. cabdirect.org/cabdirect/abstract/19641101733

Garg, D. K., L. E. Bendixen, and S. R. Anderson. 1967. "Rhizome differentiation in yellow nutsedge." Weeds 15: 124-128. http://www.jstor.org/stable/pdf/4041180.pdf?refre qid=excelsior\%3Acaabf894bbb189f660 cfad2d73d3eecf

Hall, D. G., G. S. Nuessly, and R. A. Gilbert. 2007. Sugarcane Borer in Florida. ENY666. Gainesville: University of Florida Institute of Food and Agricultural Sciences. http://ufdcimages.uflib.ufl.edu/IR/00/00/30/41/00001/SC01100.pdf

Hayden, J. E. 2012. "Mexican Rice Borer, Eoreuma loftini (Dyar) (Lepidoptera: Crambidae: Crambinae) in Florida." FDACS-P-01827. Pest Alert: Florida Department of Agriculture and Consumer Services, Division of Plant Industry. Accessed on April 12, 2018. http://www.freshfromflorida. com/content/download/68337/1613991/Pest_Alert_-_Eoreuma_loftini,_Mexican_Rice_Borer.pdf
Horowitz, M. 1972. "Development of Cynodon dactylon (L.) Pers." Weed Research 12: 207-220. http://onlinelibrary.wiley. com/wol1/doi/10.1111/j.1365-3180.1972.tb01209.x/abstract

Magarey, R. C., A. Royal, D. J. Williams, and J. I. Bull. 2011. "A brief history of disease epidemics in Queensland and of some economic outcomes." Proceedings of the Australian Society of Sugar Cane Technologists 33: 12 pp. https://www. assct.com.au/media/pdfs/Ag\%2026\%20Magarey\%20et\%20 al.pdf

Nuessly, G. S., R. H. Cherry, and H. S. Sandhu. 2015. Miscellaneous Insect Pests of Florida Sugarcane. ENY-667. Gainesville: University of Florida Institute of Food and Agricultural Sciences. http://edis.ifas.ufl.edu/sc014

Odero, D. C. and J. A. Dusky. 2014. Weed Management in Sugarcane. SS-AGR-09. Gainesville: University of Florida Institute of Food and Agricultural Sciences. http://edis.ifas. ufl.edu/wg004

Odero, D. C. and D. L. Shaner. 2014. "Field dissipation of atrazine and metribuzin in organic soils in Florida." Weed Technology 28: 578-586. http://www.bioone.org/doi/ pdf/10.1614/WT-D-13-00163.1

Odero, D. C., B. Sellers, L. Baucum, and C. Rainbolt. 2014. Fall Panicum: Biology and Control in Sugarcane. SS-AGR-132. Gainesville: University of Florida Institute of Food and Agricultural Sciences. http://edis.ifas.ufl.edu/ sc079

Patterson, D. T. 1995. "Effects of environmental stress on weed/crop interactions." Weed Science 43: 483-490. http://www.jstor.org/ stable/4045584?seq=1\#page_scan_tab_contents

Purdy, L. H., L. J. Liu, and J. L. Dean. 1983. "Sugarcane rust, a newly important disease." Plant Disease 67: 1292-1296. http://www.apsnet.org/publications/PlantDisease/BackIssues/Documents/1983Articles/PlantDisease67n11_1292. pdf

Raid, R. N. 1989. "Physiological specialization in sugarcane rust (Puccinia melanocephala) in Florida." Plant Disease 73: 183. http://www.apsnet.org/publications/PlantDisease/ BackIssues/Documents/1989Abstracts/PD_73_183D.htm

Raid, R. N. and J. C. Comstock. 2006. Sugarcane Rust Disease. SS-AGR-207. Gainesville: University of Florida Institute of Food and Agricultural Sciences. http://ufdcimages.uflib.ufl.edu/IR/00/00/30/39/00001/SC00700.pdf 
Raid, R. N. and P. Rott. 2015. Sugarcane Pokkah Boeng Disease. SS-AGR-204. Gainesville: University of Florida Institute of Food and Agricultural Sciences. http://edis.ifas. ufl.edu/sc004

Raid, R. N., J. C. Comstock, and N. Glynn. 2011. "Yield loss incited by orange rust (Puccinia kuehnii) on a highly susceptible sugarcane cultivar in Florida." Journal American Society of Sugar Cane Technologists 31: 66-67. http://www. assct.org/journal/JASSCT\%20PDF\%20Files/Volume\%2031/ rpvASSCTabstracts2011.pdf

Roberts, H. A. and P. M. Feast. 1973. "Emergence and longevity of seeds of annual weeds in cultivated and undisturbed soil." Journal of Applied Ecology 10: 133-143. http:// www.jstor.org/stable/pdf/2404721.pdf

Rott, P. (Ed.) 2017. Achieving sustainable cultivation of sugarcane. Volume 1: Cultivation techniques, quality and sustainability. Cambridge, UK: Burleigh Dodds Science Publishing. 360 pp. https://shop.bdspublishing.com/ checkout/Store/bds/Detail/WorkGroup/3-190-56201

Rott, P. (Ed.) 2018. Achieving sustainable cultivation of sugarcane. Volume 2: Breeding, pests and diseases. Cambridge, UK: Burleigh Dodds Science Publishing. 445 pp. https://shop.bdspublishing.com/checkout/Store/bds/Detail/ WorkGroup/3-190-56202

Rott, P. and J. C. Comstock. 2015. Sugarcane Smut Disease. SS-AGR-208. Gainesville: University of Florida Institute of Food and Agricultural Sciences. http://edis.ifas.ufl.edu/ sc008

Rott, P., R. A. Bailey, J. C. Comstock, B. J. Croft, and A. S. Saumtally. (Eds.) 2000. A Guide to Sugarcane Diseases. Montpellier: CIRAD/ISSCT, La Librairie du Cirad. 339 pp. https://www.amazon.co.uk/guidesugarcane-diseases-Rep\%C3\%A8res-CIRAD/ $\mathrm{dp} / 2876143860$

Rott, P., S. Sood, J. C. Comstock, R. A. Gilbert, and H. S. Sandhu. 2014a. Sugarcane Ratoon Stunting. SS-AGR-202. Gainesville: University of Florida Institute of Food and Agricultural Sciences. http://edis.ifas.ufl.edu/sc002

Rott, P., S. Sood, J. C. Comstock, R. N. Raid, N. C. Glynn, R. A. Gilbert, and H. S. Sandhu. 2014b. Sugarcane Orange Rust. SS-AGR-378. Gainesville: University of Florida Institute of Food and Agricultural Sciences. http://edis.ifas. ufl.edu/sc099
Rott, P., J. C. Comstock, R. A. Gilbert, and H. S. Sandhu. 2015. Sugarcane Mosaic. SS-AGR-209. Gainesville: University of Florida Institute of Food and Agricultural Sciences. http://edis.ifas.ufl.edu/sc009

Rott, P., C. Kaye, M. Naranjo, J. M. Shine, Jr., S. Sood, J. C. Comstock, and R. Raid. 2016. "Controlling sugarcane diseases in Florida: a challenge in constant evolution." Proceedings of the International Society of Sugar Cane Technologists 29: 595-600. http://members.issct.org/prozone/ docs/XXIX\%20ISSCT\%20Congress\%20Proceedings, \%20 Chiang\%20Mai,\%20Thailand,\%20December\%202016/ Pathology-papers/PhilippeCRottControllingsugarcanediseasesinFloridaachallengeinconstantevolution.pdf

Rott, P., H. S. Sandhu, J. C. Comstock, and R. A. Gilbert. 2017. Sugarcane Leaf Scald. SS-AGR-201. Gainesville: University of Florida Institute of Food and Agricultural Sciences. http://edis.ifas.ufl.edu/sc001

Ryan, C. C. and B. T. Egan. 1989. "Rust.” In Diseases of sugarcane. Major diseases, edited by C. Ricaud, B. T. Egan, A. G. Gillaspie, Jr., and C. G. Hughes. 189-210. Amsterdam, The Netherlands: Elsevier Science Publishers B.V.

Sandhu, H. S., and R. W. Davidson. 2017. Florida Sugarcane Cultivar Fact Sheets. Belle Glade: University of Florida Everglades Research and Education Center. http://erec.ifas.ufl.edu/featured-3-menus/extension/ florida-sugarcane-cultivar-fact-sheets/

Sandhu, H. S., L. E. Baucum, and G. S. Nuessly. 2012. Lesser Cornstalk Borer Damage to Sugarcane and the Effects of Tillage and Harvest Residue Management. ENY-454. Gainesville: University of Florida Institute of Food and Agricultural Sciences. http://edis.ifas.ufl.edu/sc094

Sandhu, H. S., M. P. Singh, R. A. Gilbert, and D. C. Odero. 2016a. Sugarcane Botany: A Brief View. SS-AGR-234. Gainesville: University of Florida Institute of Food and Agricultural Sciences. http://edis.ifas.ufl.edu/sc034

Sandhu, H. S., M. P. Singh, R. A. Gilbert, J. M. Shine, Jr., R. W. Rice, and D. C. Odero. 2016b. Maturity Curves and Harvest Schedule Recommendations for CP Sugarcane Varieties. SS-AGR-221. Gainesville: University of Florida Institute of Food and Agricultural Sciences. http://edis.ifas. ufl.edu/sc069

Sanjel, S., M. Hincapie, S. Sood, J. C. Comstock, R. N. Raid, and P. Rott. 2016. "Evidence for variation in virulence of the 
sugarcane orange rust pathogen in Florida." Sugar Journal 79(1): 29-30.

Shaner, D. L., L. J. Krutz, W. Henry, B. D. Hanson, M. D. Poteet, and C. R. Rainbolt. 2010. "Sugarcane soils exhibit enhanced atrazine degradation and cross adaptation to other s-triazines." Journal of the American Society of Sugar Cane Technologists 30: 1-10. https://pubag.nal.usda.gov/ download/44291/PDF

Stoller, E. W. and R. D. Sweet. 1987. "Biology and life cycle of purple and yellow nutsedges (Cyperus rotundus and $C$. esculentus)." Weed Technology 1: 66-73. http://www.jstor. org/stable/3986986?seq=1\#page_scan_tab_contents

USDA (United States Department of Agriculture) National Agricultural Statistics Service. 2017. “Crop Values 2016 Summary." Accessed on April 12, 2018. https://www.nass. usda.gov/

VanWeelden, M. T., S. Swanson, W. Davidson, and R. Rice. 2017. “Sugarcane Variety Census: Florida 2016." Sugar Journal 80(2): 12-24. https://www.sugarjournal.com/ product/july-2017-issue/

Vengris, J. and R. A. Damon, Jr. 1976. "Field growth of fall panicum and witchgrass." Weed Science 24: 205-208. http://www.jstor.org/ stable/4042588?seq=1\#page_scan_tab_contents

Webster, T. M. 2012. "Weed survey - Southern states. Grass subsection." Proceedings of the Southern Weed Science Society 65: 267-288. 